\title{
OSMOREGULATION IN SOME PALAEMONID PRAWNS
}

\author{
By N. Kesava Panikkar \\ From the Department of Zoology and Comparative Anatomy, University College,
} London, and the Marine Biological Laboratory, Plymouth

\author{
(Text figs. I-8)
}

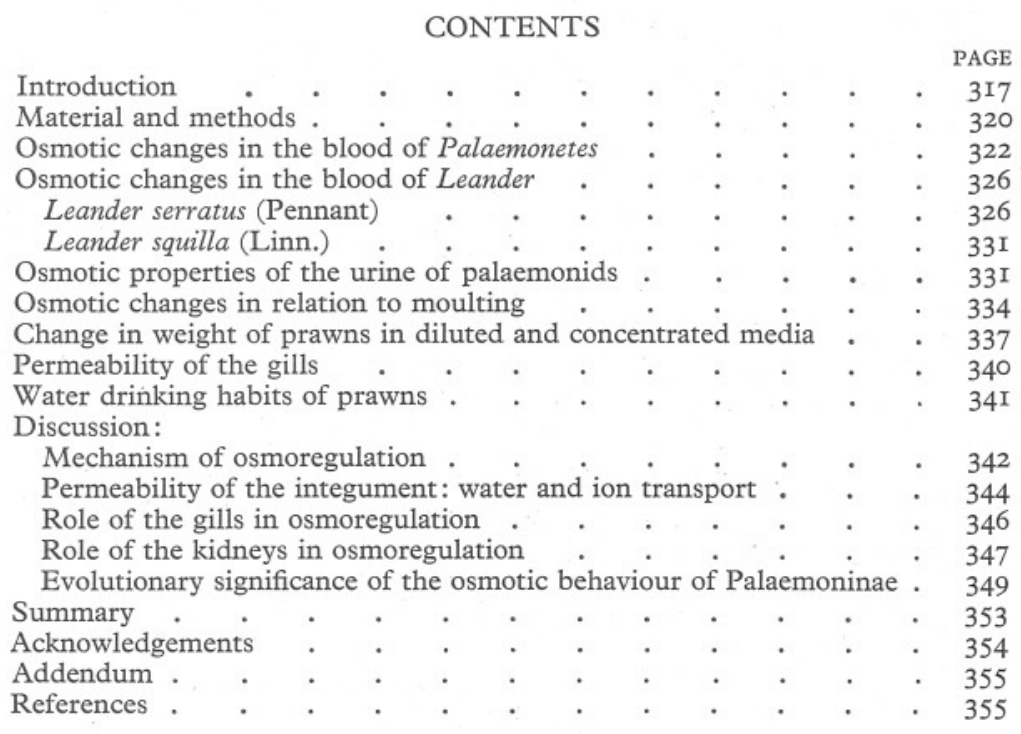

\section{INTRODUCTION}

In recent years much progress has been made in our knowledge of osmotic changes in aquatic organisms, chiefly in marine animals that can successfully withstand a certain amount of dilution of the external medium. In addition to confirming the classical findings of Bottazzi (I897, I908) that, unlike the teleosts, the body fluids of marine invertebrates and elasmobranchs are isotonic to the sea water in which they live, investigations by numerous workers have shown that the colonization of fresh and brackish waters by marine animals is closely dependent upon the development of osmoregulatory powers which attain a high degree of perfection in freshwater organisms. Schlieper and his school (Schlieper, I929, I930, 1935; Schlieper \& Herrmann, I930; Schwabe, 1933; Scholles, I933; Peters, 1935) brought evidence of the relative importance of the excretory organs in osmoregulation; this has been confirmed by other investigators who have also emphasized the question of differences 
in permeability. Finally, the discovery of Krogh (1937, 1938) that many animals in fresh water are capable of actively absorbing ions from their surroundings, even when the latter are present only in exceedingly minute quantities, has introduced a new aspect to the problem of adaptation of marine animals to fresh and brackish waters.

One would normally expect a marine invertebrate to be isotonic with its medium when in sea water, and it was therefore of unusual interest to find two crustaceans in the sea-water tanks of the Plymouth Laboratory showing a blood concentration markedly hypotonic to the external medium. One is the widely distributed and well-known brackish-water prawn Palaemonetes varians (Leach) (Panikkar, I939) and the other the common marine prawn Leander serratus (Pennant) (Panikkar, I940a). A similar behaviour was also later discovered in Leander squilla (L.). The difficulty these animals have to overcome is not that of maintaining a higher concentration of blood in an external medium of low concentration, which we find in most estuarine animals, but of keeping the blood dilute in defiance of the more concentrated external medium and the consequent prevention of loss of water from the tissues. This condition, however, changes when these same species are in brackish or fresh water, where the body fluids have to remain in a state of definite hypertonicity. The mechanism of osmoregulation needs to be equally efficient in maintaining a stable hypotonicity when in sea water and hypertonicity when in fresh or brackish water.

Among marine invertebrates, the few known instances of slight hypotonicity when in sea water are some of the grapsoid and ocypodid crabs (Edmonds, I935; Baumberger \& Olmsted, I928; Schwabe, I933; Conklin \& Krogh, I938; Pora, 1939; Pearse, I932) which belong to groups that have become semiterrestrial in habits (Table I). Other parallel instances are the highly specialized brine shrimp Artemia (Medwedewa, I927; Kuenen, 1939), the insects that can inhabit salt water (Beadle, I939; Claus, I937; Wigglesworth, I933, 1938), and certain permanently attached parasites that feed entirely on hypotonic blood (Panikkar \& Sproston, I94I).

The general condition observed in these prawns is similar to that of the marine teleosts, which are always hypotonic in sea water and hypertonic in fresh. The peculiar osmotic behaviour in the prawns here described becomes still more significant when the habits and distribution of the group to which they belong are considered. Palaemonetes varians is known to exist in two distinct varieties, a freshwater and a brackish-water one, confined respectively to the southern and north-western parts of Europe; the widely distributed genus Leander includes marine, estuarine and freshwater species. Can we correlate their osmotic behaviour with their plasticity of habits and the ability of certain palaemonid prawns to migrate into fresh water? It seems reasonable to assume that the osmotic independence shown by L. serratus and L. squilla must have been acquired in fresh water at some period in their evolutionary history, and, if this assumption is correct, we are dealing with a remarkable 


\section{Table I. Crustacea which are Hypotonic in Sea Water or Concentrated Salt Water*}

Species
Crustacea: Phyllopoda

Artemia salina

Crustacea: Copepoda

Lernaeocera branchialis

Crustacea: Decapoda

Palaemonetes varians

Leander serratus

Leander squilla

Grapsus grapsus

Pachygrapsus marmoratus

Pachygrapsus crassipes

Leptograpsus variegatus Heloecius cordiformis

Eriocheir sinensis

Ocypoda albicans Cardisoma guanhum

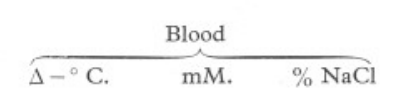

External medium

\begin{tabular}{|c|c|c|c|c|c|c|}
\hline $\begin{array}{l}0.70 \\
0.76\end{array}$ & $\begin{array}{l}205 \\
222\end{array}$ & $\begin{array}{l}\mathrm{I} \cdot 20 \\
\mathrm{I} 30\end{array}$ & $\begin{array}{l}2.75 \\
4.85\end{array}$ & $\begin{array}{r}804 \\
\end{array}$ & $\begin{array}{l}4.70 \\
8.30\end{array}$ & Medwedewa \\
\hline $\begin{array}{c}0.76 \\
0.70-0.82\end{array}$ & $\begin{array}{c}222 \\
205-240\end{array}$ & $\begin{array}{l}1 \cdot 30 \\
I \cdot 2-1 \cdot 4\end{array}$ & $\begin{array}{l}4.85 \\
3.39\end{array}$ & $\begin{array}{r}1420 \\
992\end{array}$ & $\begin{array}{l}8.30 \\
5.80\end{array}$ & \\
\hline I. $28-1 \cdot 52$ & $376-445$ & $2 \cdot 2-2 \cdot 6$ & 10.16 & 2976 & $17 \cdot 40$ & $\begin{array}{l}\text { Kuenen } \\
\text { Panikkar \& }\end{array}$ \\
\hline$[\cdot 17-1 \cdot 63$ & $342-479$ & $2 \cdot 0-2 \cdot 8$ & I. $97-2.04$ & $577-599$ & $3.4-3.5$ & Sproston \\
\hline
\end{tabular}

$\left\{\begin{array}{lll}\mathrm{I} \cdot 28-\mathrm{I} \cdot 40 & 376-4 \mathrm{II} & 2 \cdot 2-2 \cdot 4\end{array}\right.$

I.93-2.04

$577-599$

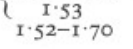

$\begin{array}{cc}450 & 2 \cdot 63 \\ 445-498 & 2 \cdot 6-2 \cdot 9\end{array}$

$2 \cdot 79$
$\mathrm{I} \cdot 93-2 \cdot 04$

$565-599$
817
$565-599$

$\left.\begin{array}{c}3 \cdot 3-3 \cdot 5 \\ 4 \cdot 78\end{array}\right\}$ Panikkar

I. $46-I \cdot 52$

428-445

$\mathrm{I} \cdot 92$
$2 \cdot 0 \mathrm{I}-2 \cdot \mathrm{II}$

563
$589-618$

2.5-2.6

I.93-2.04

565-599

I. 32

387

$3 \cdot 29$
$3 \cdot 4-3 \cdot 6$

$2 \cdot 04$
$2 \cdot 20-2 \cdot 33$

599
$645-68$

$3 \cdot 5$
$3 \cdot 8-4$

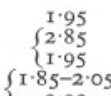

571
835
571

535
$57 \mathrm{I}$
$54 \mathrm{I}-600$
679

$3 \cdot 3$
$4 \cdot 9$
$3 \cdot 3$
$3 \cdot 2-3$
$4 \cdot 0$

I.97

577

3

$\left\{\begin{array}{l}1.32 \\ 2.265\end{array}\right.$

679

$\mathrm{I} \cdot 70$
$\mathrm{I} \cdot 66$
$\mathrm{I} \cdot 65$

498
486
483
2.13
3.40

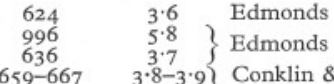

$2 \cdot 20-2 \cdot 28$

744

$\left.\begin{array}{c}3 \cdot 8-3 \cdot 9 \\ 4 \cdot 4\end{array}\right\} \underset{\text { Krogh }}{\text { Conklin } \&}$

$2 \cdot 04$
$2 \cdot 04$

599
599
599

3.

$\begin{array}{ll}3.5 & \text { Pearse } \\ 3.5 & \text { Pearse }\end{array}$

Pearse
Date

1927

1939

I94I

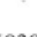

939

1940

I $94 \mathrm{I}$
$\mathrm{I} 932$

1932
1933

I928

1935

1935

1938

I932)

1932
1932
1932
Remarks

Barger's method. Values for external

Barger's method

Vapour pressure of blood of $q$ which is permanently attached to fish.

Vapour pressure method. Details in

this paper
Vapour pressure method. Details in this paper. Also confirmed by Vapour pressure method. Details in this paper

Freezing-point. Also confirmed by

Freezing-point. Hypotonicity disappears in certain stages of moult Freezing-point

Freezing-point

Vapour pressure method. Hypotonicity apparent only in concen-

Land crabs. Freezing-point method

* Values of $\Delta$ and $\mathrm{mM}$. given in this table are based on the relationship that $0.293 \mathrm{~mol} . \mathrm{Na}$ (or $\mathrm{Cl}$ ) gives a depression of freezing-point of $-\mathrm{I} \cdot 0^{\circ} \mathrm{C}$. 
group of crustaceans which had at one time become accommodated to life in fresh water and has since returned to a marine habitat. The osmotic adaptation involved is of interest because its object is the converse of what is seen in euryhaline animals. The present paper is an attempt to elucidate this osmoregulatory mechanism as studied by changes in total osmotic pressure of blood and urine, and deals with the problem as viewed from the general biological standpoint; the question of ionic regulation will be dealt with in a subsequent paper.

\section{MATERIAL AND MethodS}

The prawns used in this investigation were obtained at Plymouth, Leander serratus from the Sound, L. squilla from Laira, and Palaemonetes varians from Chelson Meadow. They were stocked in circulation tanks. No special attempt was made to feed Palaemonetes, but Leander was now and then fed with bits of Sepia and mussels. Judged by the comparatively low mortality among prawns kept in tanks it may be concluded that they remain in a healthy state under circulation. For experimental purposes they were transferred to different media prepared from clean sea water, aerated and kept in large glass jars. The tank water is more saline than outside sea water and has an osmotic pressure of $3.3-3.5 \% \mathrm{NaCl}$; it has a slightly higher calcium content (0.015 $\mathrm{M}$ as against $0.0098 \mathrm{M}$ for outside sea water (Cooper, 1932)). The $p \mathrm{H}$ is about $8 \cdot 0$, but is subject to slight variation (Atkins, I922). Dilutions of sea water were always made with Plymouth tap water, which is a very soft water with a slight trace of chloride and about 3 parts per million of silica. Experimental animals were not fed; nor were the jars aerated after the animals had been put into them. Artificial sea water was made with $0.6 \mathrm{M} \mathrm{NaCl}, 0.6 \mathrm{M} \mathrm{KCl}$, $0.4 \mathrm{M} \mathrm{CaCl}_{2}$ and $0.4 \mathrm{M} \mathrm{MgCl}_{2}$ solutions mixed in the proportion of $80 \mathrm{I} .9$, $17 \cdot 2,27 \cdot 2$ and $139 \cdot 6 \mathrm{ml}$. respectively, along with 2 drops of $M \mathrm{NaHCO}_{3}$ for every $100 \mathrm{ml}$. of the mixture, and brought to $p \mathrm{H} 8$ with $\mathrm{NaOH}$. Concentrated sea water was prepared by the addition of Tidmann's sea salt to clean sea water, care being taken to bring the $p \mathrm{H}$ to normal by appropriate buffering.

Estimations of osmotic pressure were made by Baldes's modification of the Hill thermo-electric technique (Baldes, 1934; Hill, 1930, 1931). The standard solutions employed for comparing the vapour pressures were over a fairly wide range, i.e. between $\mathrm{I} \cdot 8$ and $2 \cdot 5 \% \mathrm{NaCl}$ for the blood of Palaemonetes and between 2.0 and $3.0 \% \mathrm{NaCl}$ for that of Leander. After mounting the solutions on the thermocouples in a moist chamber, they were equilibrated in a thermostat kept constant at $20.8^{\circ} \mathrm{C} . \pm 0.00 \mathrm{I}$, and the deflexions taken from a Downing (moving-coil) galvanometer of sensitivity I.28 $\times 10^{-8} \mathrm{~V} . / \mathrm{mm}$. at a distance of $3 \mathrm{~m}$. Using tested thermocouples, I mm. deflexion on the scale was equivalent to an e.m.f. caused by solutions differing in strength by $0.005 \% \mathrm{NaCl}$, so that, using a magnifying glass, differences up to half the above figure could be read on the scale. All estimations were made in duplicate 
on two separate instruments, and most of the readings were also taken in the same instrument with the unknown sample placed in a 'normal' and a 'reversed' position. The data given in the tables and graphs are the mean values of the readings taken with each sample. The values of osmotic pressure are throughout expressed as percentage of sodium chloride, i.e. the grams of $\mathrm{NaCl}$ dissolved in $\mathrm{IOO}$ g. of distilled water to make a solution having the same vapour pressure as the unknown at the same temperature and atmospheric pressure. Owing to variations in the salinity of the tank water, parallel estimations of osmotic pressure of tank water were made in all cases where the animals were taken from the circulation. The experimental solutions used as external media were measured in the same manner as blood and urine, but the standard solutions employed ranged from distilled water to $3.5 \% \mathrm{NaCl}$; special attention was paid to having the filter paper on the walls of the couple chamber moistened with the solutions being compared, to ensure greater accuracy (cf. Hill, I93I). In all experiments the thermocouples were calibrated both before and after a series of estimations, and the mean values taken for final calculations.

The following uniform procedure was adopted for the removal of blood from prawns. The animals were wiped with a dry towel, and the water in the gill chambers and between the cephalothoracic shield and the first abdominal segment was completely removed with strips of filter paper. A capillary pipette (specially drawn out from glass tubing cleaned in bichromate sulphuric mixture and distilled water, and kept in readiness in a desiccator) was introduced into the heart at the point where it is easily accessible from outside, i.e. under the hind-margin of the cephalothoracic shield. The blood collects in the tube because of the hydrostatic pressure and capillarity, but if larger quantities were required, the blood could be sucked in by an attached rubber tube. Blood from the pipette was transferred direct to the thermocouples (kept in the moist chamber) almost immediately after removal because of its tendency to clot, especially in Leander. When drops of blood were mounted, the first drop from the pipette was not used, nor was the last, so as to reduce the errors due to evaporation to a minimum. No animal from which blood was removed once was ever again used except for the removal of urine.

The obtaining of samples of urine was considerably more difficult. Repeated trials showed that the following method gave the best results. The prawn, after the adhering water has been wiped off, is laid on its back on a glass plate under a binocular microscope; if this proves difficult it may be kept in position by a rubber band running round the plate. By careful manipulation, the opening of the antennary gland at the base of the antenna may now be located and its outside carefully wiped with strips of filter paper. The tip of a micropipette, with an attached rubber tube, is introduced into the pore of the antennary gland and the contents sucked into the pipette. In many experiments the hydrostatic pressure of the urine inside the bladder was sufficiently high to fill the pipette without much effort. While this procedure worked well with Leander, success 
was only partial with Palaemonetes owing to its small size. Some samples were obtained from larger individuals by the same method as the above. In others, only the contents of the nephroperitoneal sac were taken for estimation of osmotic pressure. In Leander, the contents of this sac (which is in direct communication with the bladder, Fig. 5, p. 332), as obtained by dissection, had nearly the same osmotic pressure as the urine collected at the base of the antenna (Table III). Applying this information to Palaemonetes, the contents of the nephroperitoneal sac may be expected to give an indication of the properties of the urine; the source of the samples is indicated separately in the tables.

The dry weight of specimens used for estimation of water content was taken after the animals had been crushed and kept in a hot-air oven at a temperature of $105^{\circ} \mathrm{C}$. for $24-36 \mathrm{hr}$. which was about the time required to get constant weights. The weighings were to within $2.5 \mathrm{mg}$.

The freezing-point of the blood of Leander serratus was determined by a cryoscope of the Burian and Drucker model; the Beckmann thermometer was graduated to $0.02^{\circ} \mathrm{C}$. and the readings taken were correct to about $0.0 \mathrm{I}^{\circ} \mathrm{C}$.

\section{Osmotic Changes IN the Blood of PALAEMONETES}

Palaemonetes varians inhabits brackish waters in the vicinity of Plymouth and adjoining places; though it is common in waters of varying salinity on the English and Irish coasts, it is rarely, if ever, met with in the open sea. In northern and western Europe the species is known only from water with some admixture of salt, whereas in the Mediterranean it is a freshwater species; but even there it is not exclusively fluviatile as shown by Gourret's record of it from salt water in the south of France along with strictly marine species (Gurney, I923). Physiological varieties of the species have been distinguished (vide Boas, I898, for summary and literature) in accordance with the size of the egg and reproductive habits; the brackish-water form with smaller eggs and full complement of larval stages is called var. microgenitor (=var. occidentalis, Sollaud, I923) and the freshwater variety with larger and fewer eggs and a reduced development is designated var. macrogenitor (=var. lacustris von Martens). Sollaud added a third variety mesogenitor from Tunisia, but this is probably a distinct species (Gurney, I923). It may be pointed out that there is no important structural difference between these varieties. In a later paper, Sollaud (1932) has suggested that the four forms of Palaemonetes found around the Mediterranean which are usually considered as different varieties of $P$. varians are specifically distinct, though they form a natural group of their own ('clan') within the genus. Of these, $P$. varians has small eggs (microgenitor), $P$. antennarius and $P$. mesopotamicus have large eggs (macrogenitor), while $P$. mesogenitor shows the intermediate condition.

The locality from which specimens were obtained for this study is subject to wide fluctuations in salinity during the year. The Chelson Meadow consists 
of a large tract of unreclaimed land near the mouth of the Plym, from which it is separated by an embankment. Salt water enters during high tide and the excess of water drains off into the river through sluice gates. The animals that are commonly obtained with Palaemonetes in the ditches at Chelson Meadow are Potamopyrgus ${ }^{1}$ jenkinsi and Gammarus chevreuxii, both of which are well known for their high degree of tolerance to salinity changes (Sexton \& Matthews, I9I3). During the course of this work the highest salinity observed was in the summer and autumn, and the lowest during the winter (Fig. I).

The blood of Palaemonetes obtained from its natural habitats has an osmotic pressure varying between 2.0 and $2.4 \% \mathrm{NaCl}$ according to changes in the environment at different times of the year as shown in Fig. I. The results plotted indicate an almost straight-line correlation except for the values obtained during February, which are comparatively higher, and of May (summer) which are lower. The blood is hypotonic in concentrations up to about $2.25 \%$ when isotonicity is established. The blood is hypertonic in further dilutions of the environment, and the fall in osmotic pressure compared with that of the external medium is very limited, the lowest value being about $2.0 \% \mathrm{NaCl}$. The blood of prawns that were living in the sea-water tanks for some months gave values of about $2.30 \% \mathrm{NaCl}$. Thus in prawns taken from the natural habitats the maximum difference between the highest and lowest values for blood is only $0.40 \% \mathrm{NaCl}$ for a difference of nearly $3.20 \% \mathrm{NaCl}$ in the external medium, while under experimental conditions the corresponding value is nearly $0.50 \% \mathrm{NaCl}$.

The osmotic changes in the blood of Palaemonetes when transferred from sea water to different experimental media are shown in Fig. $2 \mathrm{~A}$. The curve obtained for these values does not exactly correspond with the values for specimens from Chelson Meadow (Fig. 2). The difference seen is no doubt due to the slow and prolonged acclimatization which the experimental animals are denied. But this is not explained entirely on the basis of the time factor, since experimental animals have been observed to attain a more or less steady state after some time.

Palaemonetes is able to survive sudden transfer from sea water to water of very low salinity, i.e. about $0.5 \% \mathrm{NaCl}$. The prawns remain active and healthy in spite of sudden changes in external medium and, by slow acclimatization, the animals could be brought down to water of as low an osmotic pressure as $0.0 \mathrm{\%} \mathrm{NaCl}$. If directly transferred to distilled water from sea water they survive for about 2-3 hr.; but in distilled water with a trace of sodium chloride (osmotic pressure $0.005-0.01 \% \mathrm{NaCl}$ ) they live for $24-30 \mathrm{hr}$. Six specimens acclimatized to $0.45 \% \mathrm{NaCl}$ lived for I8-22 hr. in Plymouth tap water, and their survival period could be prolonged to several days by the addition of a small quantity of $\mathrm{NaCl}$ solution so as to raise the osmotic pressure of the medium to about $0.005-0.01 \% \mathrm{NaCl}$.

Values of osmotic pressure of specimens transferred from sea water to

${ }^{1}$ Also known under the names Hydrobia and Paludestrina. 


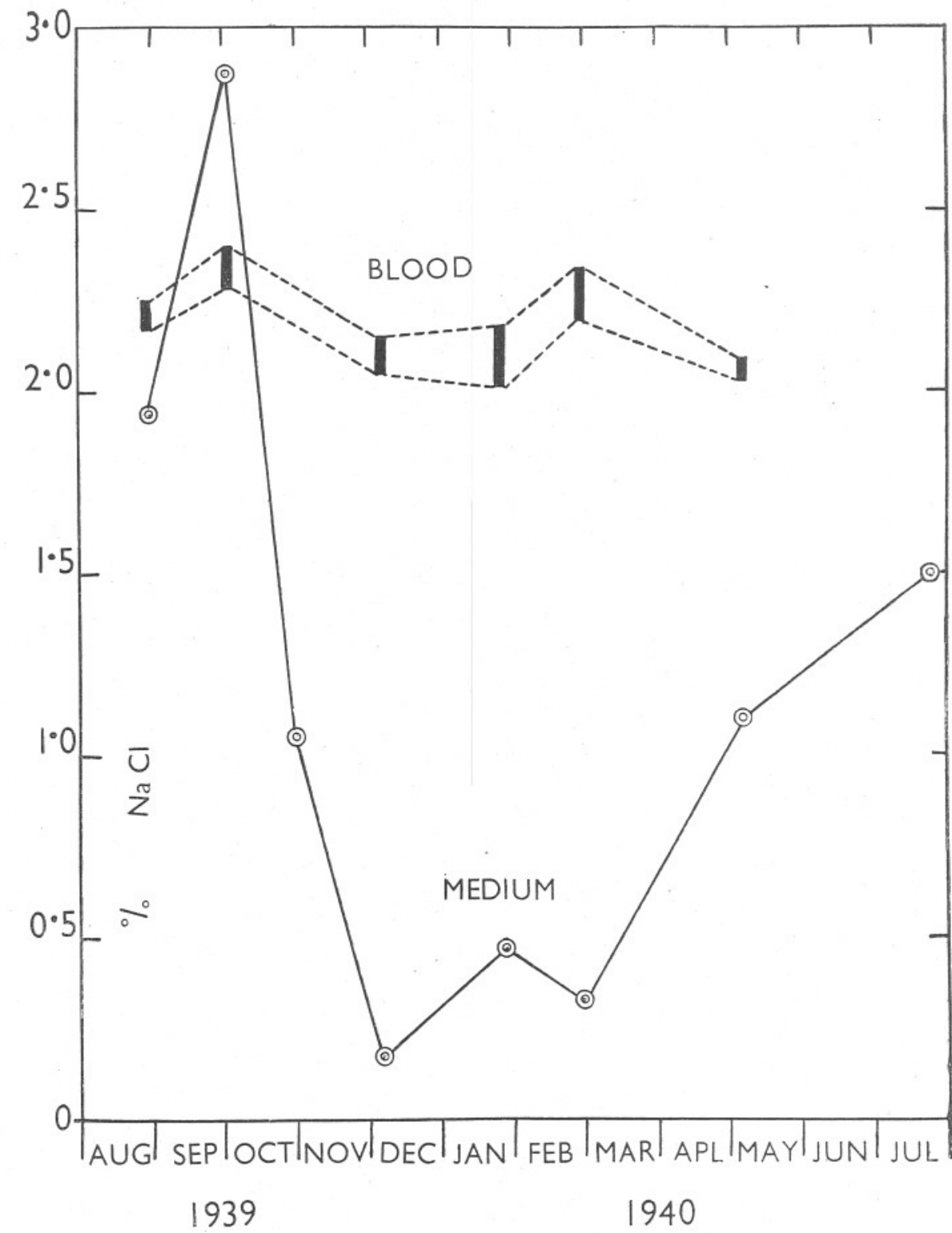

Fig. I. Seasonal changes in the osmotic concentration of the blood of Palaemonetes varians in its natural habitat at Chelson Meadow. Ordinates represent osmotic pressure of blood $(\% \mathrm{NaCl})$ and the salinity of the external medium (expressed for convenience in $\% \mathrm{NaCl})$. The range of values for blood falls between the dotted lines. 
water of low salinity and from water of low salinity to sea water are given in Figs. 3 and 4. In the first transfer (Fig. $3 a$ ) there is a steady fall in values from about $2 \cdot 4$ to nearly $2.0 \%$ within the course of 8 -Io hr., and an almost steady state is thereafter attained. The curve, however, is by no means smooth, which may be partly due to the differences in adaptive powers among the individuals taken for experiment. There is also an indication that the osmotic pressure fluctuates before a final steady state is reached, and this is also seen in animals transferred to sea water (Fig. $4 a$ ). In both experiments the animals show a direct and immediate response to changes in external osmotic pressure and the attainment of a steady state by later adjustment.

In I925 Vialli made some measurements of the osmotic pressure of the freshwater variety of Palaemonetes varians from Italy by employing Monti's method. From thermoelectric readings of what he calls the coelomic cavity, he found that the prawns showed a $\Delta$ of $-0.54^{\circ} \mathrm{C}$. which is equivalent to about $0.92 \% \mathrm{NaCl}$. Even the lowest value I have obtained in specimens acclimatized to nearly freshwater is considerably higher than Vialli's. Confirmation of his results would be of great interest, since it may indicate another physiological difference between the Mediterranean and Western European varieties.

By allowing the water in which they are kept to evaporate, or by the addition of small quantities of Tidmann's sea salt, specimens of Palaemonetes have been acclimatized to concentrations as high as $5.2 \% \mathrm{NaCl}$. From sea water the prawns can survive direct transfer to concentrated sea water having a value of $5.0 \% \mathrm{NaCl}$; but animals acclimatized to hypotonic media were unable to live long in water of $4.5 \% \mathrm{NaCl}$ after direct transfer.

Osmotic changes of Palaemonetes consequent upon direct transfer from sea water to concentrated sea water of $5.00 \% \mathrm{NaCl}$ are given in graphs $b$ and $c$, Fig. 4. There is a steady rise in the values for blood to about $3.0 \%$ within the first $4 \mathrm{hr}$., but afterwards there is great fluctuation in values. It is possible that some of the specimens which showed abnormally high values were those which in due course might have died owing to inefficient regulation, but at the time when estimations were made they were alive and active. The critical stage in adaptation is evidently after about $4-5 \mathrm{hr}$. when the osmotic pressure is already $3.0 \% \mathrm{NaCl}$, since the high degree of scatter in the values is observed only after this period. It is noteworthy that prawns that lived in the medium for 3 days and had attained a steady state also show a value of nearly $3.0 \%$. In $4.78 \% \mathrm{NaCl}$, the mean value for blood came down to about $2.6 \%$ in a week's time (Table II).

The figures obtained when animals are subjected to sudden change of environment show definitely that there is an initial rise or fall in osmotic pressure which is considerably higher or lower than the final steady value. Thus the upset of osmotic equilibrium is not avoided by the animals by passive control, but adjustment is later effected by osmotic work done by them. The fluctuations in the values may largely be due to individual differences in 
adaptive capacity owing to differences in size and moult stage, but this cannot account for the rise and fall after $4 \mathrm{hr}$. in experiments with concentrated sea water. Possibly the entry of salts into the prawns may take place discontinuously, as for example when they occasionally drink water to make up for water loss, and this is partly responsible for the wide fluctuations.

It has already been mentioned that the osmotic pressure of the blood of animals taken from the natural habitat during February was slightly higher that one would expect from the curve. Similarly there is a steady fall from February to May in spite of the rise in salinity of the medium (Fig. I). This would indicate a lower value in summer and a higher one in winter. A similar seasonal cycle has been observed by Widmann (1935) and Otto (1937) working with other Crustacea. According to their observations as well as mine, higher temperature seems to give lower values of osmotic pressure. The possible significance of this in certain problems of animal distribution has been discussed elsewhere (Panikkar, I940 b).

Palaemonetes is able to take in salt when in hypotonic media. Prawns collected from Chelson Meadow, found living in a medium of $0.175 \% \mathrm{NaCl}$ and having an average osmotic pressure of $2 \cdot 108 \% \mathrm{NaCl}$, were transferred to dilute sea water of $\mathrm{I} \cdot 450 \% \mathrm{NaCl}$. Osmotic changes cannot be expected since the new medium is also hypotonic to the blood, but after $48 \mathrm{hr}$. the average osmotic pressure of the prawns rose to $2 \cdot 290 \% \mathrm{NaCl}$. Judging from the analogy of freshwater and brackish-water organisms investigated by Krogh (1938) the gills would seem to be the primary site of absorption, though a small amount of salt may also be absorbed through the gut.

\section{Osmotic Changes IN tHe Blood of LEANDER}

\section{Leander serratus}

Leander serratus, the so-called 'common prawn', is a littoral marine species abundant in the southern parts of the North Sea and in the Mediterranean. Details of its distribution are given by Gurney (1923). Though it is able to withstand a certain amount of dilution of the environment, this prawn is essentially marine in its habits, but it is not uncommon to find it among sea weeds on the coastal regions where slight dilution of the sea water may take place from rain or river water. Unlike the closely related species L. longirostris, $L$. serratus does not seem to migrate much into rivers; nor does it show any preference for brackish water or estuarine habitats as do many other Leander.

The osmotic pressure of the blood of $L$. serratus when in sea water has a value of $2 \cdot 6-2 \cdot 9 \% \mathrm{NaCl}$. The variations of osmotic pressure among individuals of the same batch is higher in this prawn than in Palaemonetes, and, as will be shown later, much of this variation may be expected on the basis of differences in moult stages. It is worth mentioning that my records show that, as in Palaemonetes, the blood shows a higher value in winter than in summer. The mean value for the blood of twelve prawns of about the same intermoult 
period, as judged by appearance, taken from sea water of $3.45 \% \mathrm{NaCl}$ in summer was $2.60 \% \mathrm{NaCl}$, but the corresponding value for winter was $2.85 \%$. While there is no perceptible difference between males and females not in berry, the ovigerous females on the whole show a slightly higher value of $2.95 \%$ (winter). I have not been able to find any definite correlation between size and osmotic pressure of blood among individuals averaging from

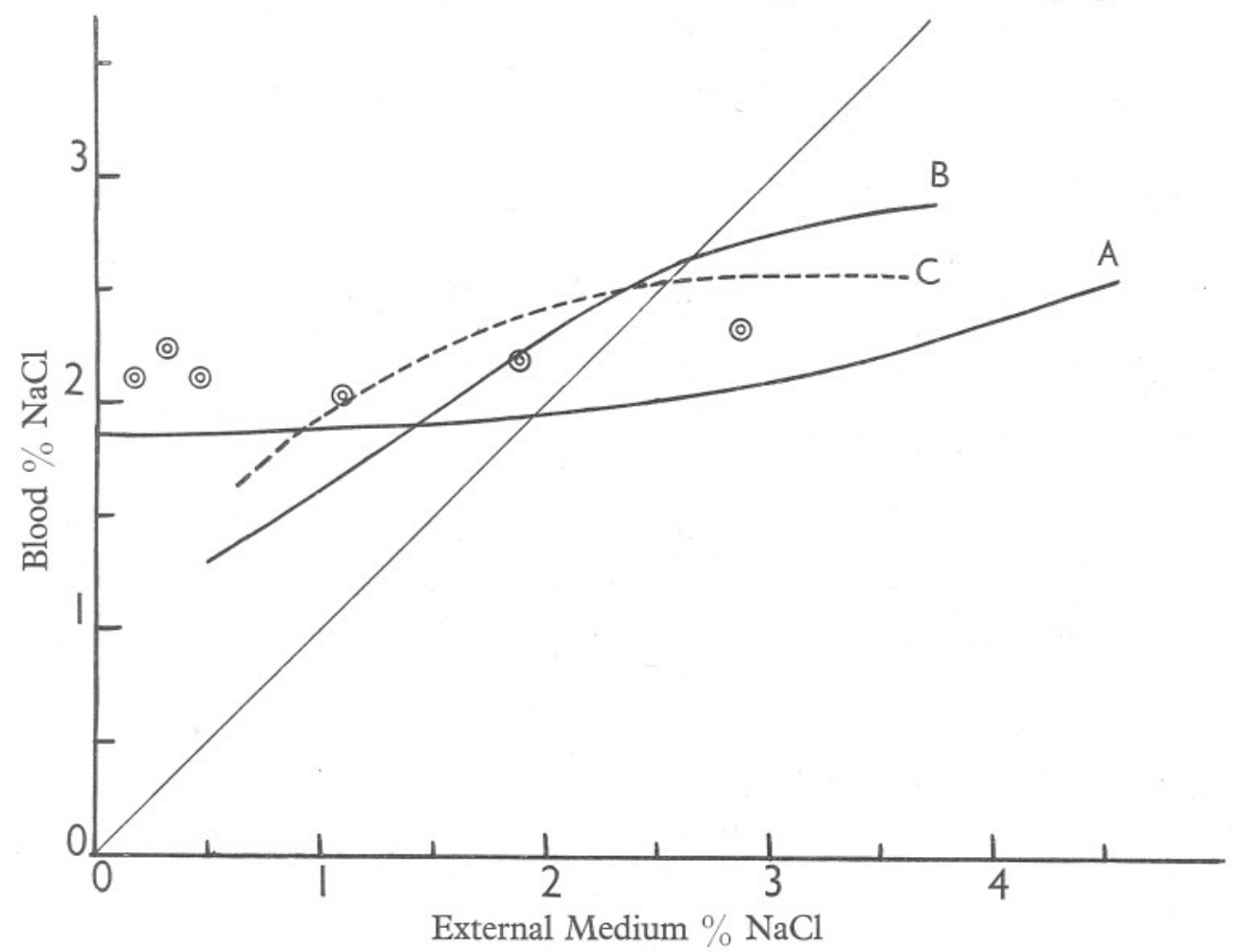

Fig. 2. Osmotic pressure (in $\% \mathrm{NaCl}$ ) of the blood of (A) Palaemonetes varians, (B) Leander serratus and (C) Leander squilla (dotted line) in different concentrations of the external medium measured under experimental conditions. Abscissae, external medium; ordinates, blood. Straight line indicates where points would fall if external and internal media were isotonic. Circles represent osmotic pressures (mean values only) of Palaemonetes from water of different salinities in its natural habitat.

35 to $80 \mathrm{~mm}$. in length, but the larger prawns of 96-100 mm. usually show higher values than smaller individuals of the same batch. In the absence of data on the moult stage of each prawn investigated, I am not inclined to emphasize these differences, especially when we consider that the larger prawns have a longer intermoult period.

Osmotic pressure of the blood of Leander serratus was also measured by the freezing-point method. Blood from about twenty-five specimens was collected for this purpose and allowed to stand for $6 \mathrm{hr}$., after which the clear 
bluish serum was separated and poured into the cryoscope. In two series of estimations with two sets of prawns taken from circulation in January I94I, $\Delta$ values of $-\mathrm{I} \cdot 70$ and $-\mathrm{I} \cdot 66^{\circ} \mathrm{C}$. were obtained for the blood serum and of $-2.06^{\circ} \mathrm{C}$. for sea water. These values are in fairly close agreement with the results obtained by the vapour-pressure method.

Table III and the graph B in Fig. 2 show the osmotic relations of $L$. serratus in different dilutions of the environment. The prawn is homoiosmotic in normal sea water down to a dilution of sea water equivalent to $2.5 \% \mathrm{NaCl}$, which is the approximate point of isotonicity. There is a steady decline in value after this, but even in lower dilutions the ability of the animal to maintain a hypertonic blood concentration is well marked. The curve has thus the essential features of the Palaemonetes curve, the differences observed being caused by the lower osmotic deficit when in sea water, and absence of efficient regulation in very dilute sea water. I have not been able to acclimatize Leander serratus to live in water below $0.6 \% \mathrm{NaCl}$; the mortality was very high in experiments with water of $0.6-\mathrm{I} \cdot 0 \% \mathrm{NaCl}$, and no prawn which lived for a few days in these dilute media showed an osmotic pressure less than about I. $6 \% \mathrm{NaCl}$.

Acclimatization experiments show that the degree of tolerance to changes in the external medium is very limited in Leander as compared with Palaemonetes, but certainly much better developed than in most marine invertebrates. It can survive direct transfer to media as low in concentration as I. $6 \% \mathrm{NaCl}$. Even in lower dilutions the prawns live for 3-4 hr. after direct transfer and may recover if taken back to sea water before they have become comatose. In all these the size of the individual and the moult stage seem to have a close bearing on the ability to survive sudden salinity changes. Smaller juvenile prawns have a greater degree of tolerance than larger ones, and the ovigerous females have the minimum amount of tolerance to diluted media. Similarly, the freshly moulted individuals die in a few hours if transferred to sea water of even moderate dilutions, such as $2.0 \% \mathrm{NaCl}$. The period of survival after such changes is longer the longer the time that has elapsed after moult.

Slow acclimatization to concentrated sea water is possible, the maximum upper limit being about $3.9 \% \mathrm{NaCl}$, the osmotic pressure of blood rising in the meantime to $3 . \mathrm{I} \% \mathrm{NaCl}$. This value is not represented in curve B, Fig. 2, since the observations have not been extensive.

Osmotic changes of prawns when they are directly transferred to dilute sea water are shown in Fig. 3. As may be expected, the time taken to reach the lowest value varies according to the strength of the experimental medium and the sizes of individuals, the small prawns showing a higher rate of change. The dilution curve is steady until the final equalization, followed by a slight rise, the curve having the same shape as the one obtained for Palaemonetes.

Like Palaemonetes, Leander serratus is able to absorb salt from hypotonic surroundings. Prawns acclimatized to $50 \%$ sea water (osmotic pressure 


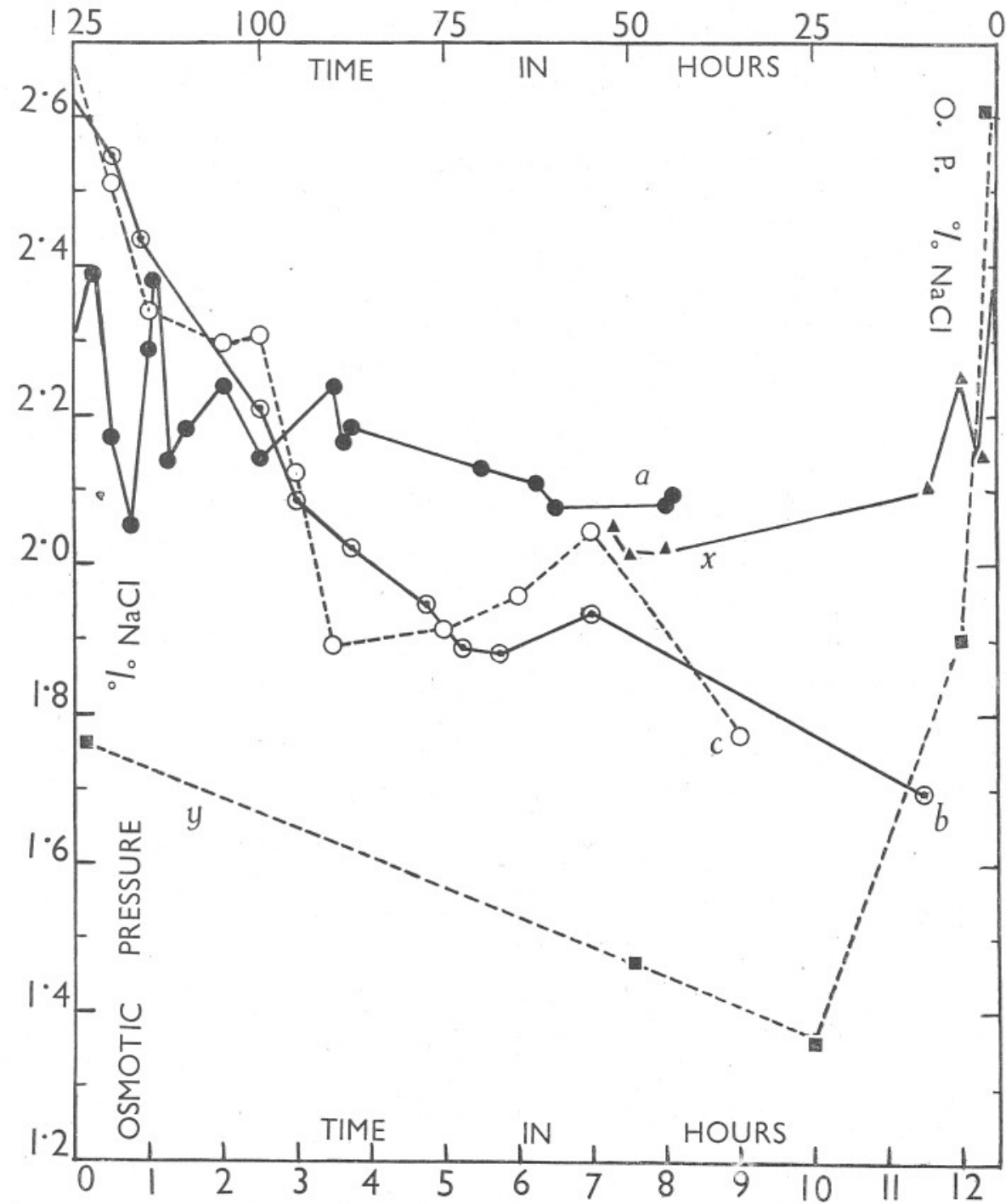

Fig. 3. Osmotic changes of Palaemonetes varians and Leander serratus when transferred directly from normal sea water to dilute sea water. Abscissae, time in hours; ordinates, osmotic pressure of blood in \% NaCl. (a) Palaemonetes from sea water to dilute sea water of $0.565 \% \mathrm{NaCl}$ (9. xii. 39); (b) Leander from normal sea water to dilute sea water of $0.616 \% \mathrm{NaCl}$ (29. xi. 39); (c) Leander from sea water to dilute sea water of $0.65 \%$ $\mathrm{NaCl}$ (dotted line, 6. xii. 39); (x) same experiment as (a) but continued for $54 \mathrm{hr}$.; (y) Leander, same experiment as (b) but carried on for I24 hr. (dotted line). Lower time scale for $(a),(b)$ and $(c)$; upper scale for $(x)$ and $(y)$. 


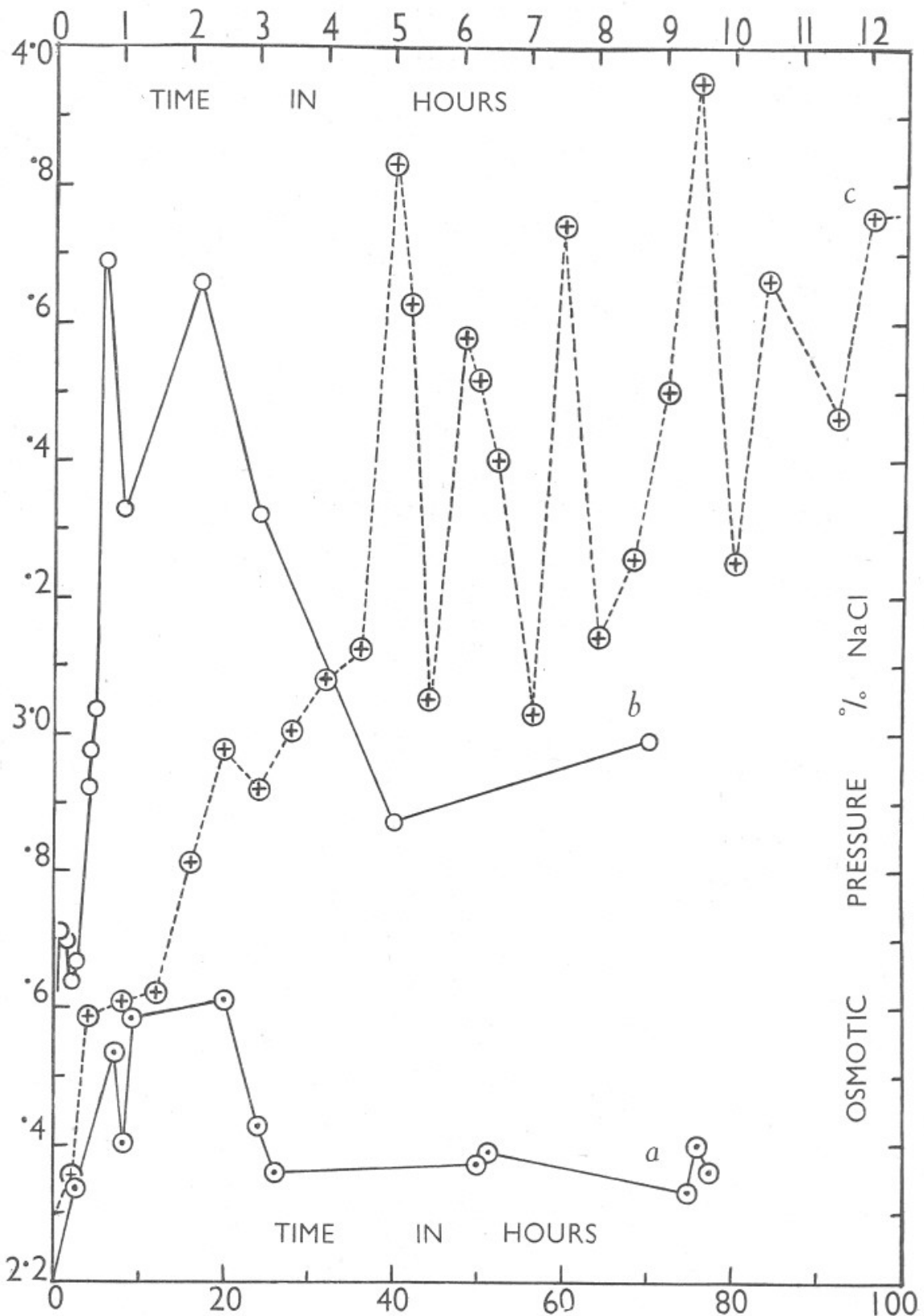

Fig. 4. Osmotic changes of Palaemonetes varians on direct transfer to concentrated media. Abscissae, time in hours; ordinates, osmotic pressure of blood in \% NaCl. (a) From water of $0.325 \% \mathrm{NaCl}$ (natural habitat) to circulating sea water of $3.34 \mathrm{I} \% \mathrm{NaCl}$ (I. iii. 40); (b) from sea water of $3.4 \% \mathrm{NaCl}$ to concentrated sea water of $5.0 \% \mathrm{NaCl}$ (3. iii. 40); (c) from sea water of $3.4 \% \mathrm{NaCl}$ to $5.5 \% \mathrm{NaCl}$ (dotted line) the changes observed during the first I2 hr. Lower time scale for $(a)$ and $(b)$; upper for $(c)$. 
$\mathrm{I} \cdot 720 \% \mathrm{NaCl}$ ) and having a mean osmotic pressure of $2 \cdot 3 \% \mathrm{NaCl}$ showed an increase in value up to $2.5 \% \mathrm{NaCl}$ in $\mathrm{I} 4 \mathrm{hr}$. when transferred to sea water of $2 \cdot 2 \% \mathrm{NaCl}$.

\section{Leander squilla}

Leander squilla (Linn.) is littoral in habits; the species enjoys a wide distribution, being common in the Baltic Sea, Scandinavian, Dutch, British and French coasts, the Mediterranean and the Black Sea (Gurney, 1923). It is frequently encountered in brackish water in the Black Sea and in pools in salt marshes on the English coasts along with Palaemonetes varians. In addition to occurring in the sea at Plymouth, the species has been recorded a few miles up the River Lynher, River Tamar and at Laira; in the spring of 1940 a few juvenile individuals were obtained along with $P$. varians at the Chelson Meadow. Gurney mentions that there can be no doubt that the whole larval life is spent in the sea. It was difficult to obtain a plentiful supply of this prawn during the period of study, and the observations on it are therefore not very extensive.

Fig. $2 \mathrm{C}$ gives the values of osmotic pressure of prawns from different salinities. In normal sea water the blood is equivalent to about $2.6 \% \mathrm{NaCl}$; approximate isotonicity is established in a medium equivalent to about $2.5 \% \mathrm{NaCl}$, and in lower dilutions the blood is hypertonic to an appreciable extent indicating effective regulation. The curve obtained when the results are plotted is very similar to that for Leander serratus. It is noteworthy, however, that the optimum value in sea water is slightly lower than in L. serratus $(2.6$ as against $2.8 \%$ ), and that the homoiosmotic behaviour is even better developed than in the former species. The osmotic adaptation is therefore intermediate between that of Palaemonetes varians and Leander serratus, and this is precisely what one would expect from its habits and distribution, and from the results obtained by Mathias (1938) and Pora (1938) in regard to its ability to withstand experimental changes in the external medium.

\section{Osmotic Properties of the Urine of Palaemonids Description of the Excretory Organs}

The main excretory organs of prawns are the green glands or antennary glands which become functionally active as soon as the shell glands or maxillary glands disappear at the end of larval life. The green glands of the Palaemoninae have been described by Grobben (I880), Weldon (I889, I89I), Marchal (I892), Allen (I892b), Cuénot (I895) and Patwardhan (I937). The excretory pore, found at the base of the antennary peduncle in close proximity with the labrum, leads through the ureter into the bladder, to one side of which is attached the end-sac and the convoluted tubules of the labyrinth Fig. 5). The end-sac is a small, compact, specialized structure composed of 
an outer layer of connective tissue containing blood spaces and an inner layer; thrown into folds projecting into the lumen of the sac, which is lined with large excretory epithelial cells having conspicuous nuclei and granular cytoplasm. The excretory tubules forming the glandular plexus or the labyrinth anastomose freely with one another, but they communicate by means of a common opening with the end-sac and by several openings with the bladder. The walls of these tubules are formed by a single layer of excretory epithelial cells, while the intervening spaces between the tubules are filled with loose connective tissue and numerous blood lacunae. The bladder wall is extremely thin and lined with epithelial cells resembling those seen in the tubules.

Of special significance in the excretory system of the Palaemoninae is the large median renal or nephroperitoneal sac which is an unpaired structure lying in the cephalothorax dorsal to the cardiac stomach and ventral to the ophthalmic artery and the median dorsal sac. This communicates with the bladder by means of two lateral nephroperitoneal ducts which are also connected by a transverse commissure passing in front

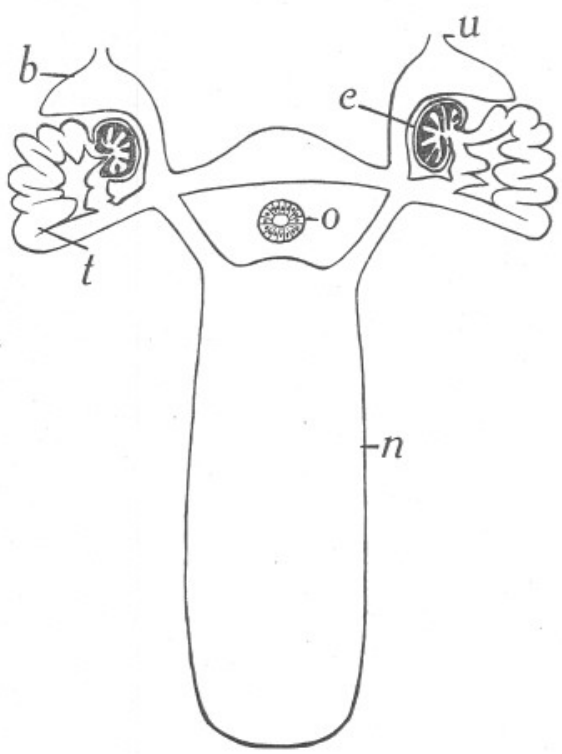

Fig. 5. Diagram of the palaemonid excretory system (after Weldon). b. bladder; $e$. endsac; $n$. nephroperitoneal sac; $o$. oesophagus; $t$. tubule; and $u$. ureter. of the oesophagus. The renal sac is composed of a single layer of flattened excretory epithelium which both Weldon and Marchal found capable of absorbing indigocarmine and similar substances when they are injected into the blood of the living animal. From a study of the development of the excretory organs of Palaemonetes varians, Allen ( $1892 b$ ) demonstrated that the nephroperitoneal sac is formed by the fusion of the backward extensions of the two bladders. $\mathrm{He}$ also drew attention to the presence of a completely closed dorsal sac (the median dorsal blood sinus of Weldon) which lies upon the nephroperitoneal sac; it is probably coelomic in origin and persists in the adults of Palaemon (=Leander) and Palaemonetes. According to him it does not contain blood since blood corpuscles are never met with in the sacs of the larvae or of the adults; nor has any direct communication been observed between the dorsal sac and the blood sinuses of the body.

In Tables II and III are given the values of the osmotic pressure of the urine of Palaemonetes and Leander. In general the osmotic pressure of the urine is closely similar to that of the blood, though slight variations on either side are observed, as was also noted by Picken (1936) and Nagel (1934) in 
Carcinus. The results also indicate that the general rule of isotonicity with blood is not affected by the differences in the nature of the medium, whether hypotonic or hypertonic. In Palaemonetes transferred to fresh water with a little $\mathrm{NaCl}$, the urine was found to be slightly hypotonic to the blood, which also had a comparatively low value. But even here the extent of hypotonicity is so small that it may not be considered far outside the range of experimental variation, and further, the steady state had not been attained as evidenced by the low value for blood.

Table II. Osmotic Properties of the Blood and Urine of PALAEMONETES VARIANS IN DifFerent Media. MARCH 1940

\begin{tabular}{ccl} 
No. & $\begin{array}{c}\text { Length } \\
\text { mm. }\end{array}$ & \multicolumn{1}{c}{ Time } \\
I & 28 & I week \\
2 & 29 & I week \\
3 & 27 & I week \\
4 & 27 & I0 days \\
5 & 27 & I0 days \\
6 & 27 & I5 days \\
7 & 28 & I month \\
8 & 29 & Nat. habitat \\
9 & 28 & Nat. habitat \\
I0 & 28 & Nat. habitat \\
II & 27 & Nat. habitat \\
I2 & 33 & I5 days \\
I3 & 32 & I5 days \\
I4 & 32 & I5 days \\
I5 & 22 & 44 hr. \\
I6 & 20 & 45 hr. \\
I7 & 28 & Gradually \\
& & acclimatized
\end{tabular}

Osmotic pressure, $\% \mathrm{NaCl}$

* Sample from nephroperitoneal sac.

No. I5 showed signs of distress; no. I6 was a healthy specimen.

\section{Table III. Osmotic Properties of the Blood and Urine OF LEANDER SERRATUS. FebruARY I940}

\begin{tabular}{|c|c|c|c|c|}
\hline $\begin{array}{l}\text { Length } \\
\mathrm{mm} .\end{array}$ & Time & $\begin{array}{l}\text { o.P. medium } \\
\% \% \mathrm{NaCl}\end{array}$ & $\begin{array}{l}\text { o.p. blood } \\
\% \mathrm{NaCl}\end{array}$ & $\begin{array}{l}\text { o.p. urine } \\
\% \mathrm{NaCl}\end{array}$ \\
\hline $\begin{array}{l}90 \\
\text { (ov. female) }\end{array}$ & 2 months & $3 \cdot 246$ & 2.960 & 2.991 \\
\hline $\begin{array}{l}94 \\
90 \\
90 \\
\text { (ov, female) }\end{array}$ & $\begin{array}{l}2 \text { months } \\
2 \text { months }\end{array}$ & $\begin{array}{l}\begin{array}{l}3.246 \\
3 \cdot 410\end{array}\end{array}$ & 3.046 & $\begin{array}{l}2 \cdot 955 \\
3.000\end{array}$ \\
\hline $\begin{array}{l}95 \\
\text { (ov. female) }\end{array}$ & 2 months & $3 \cdot 400$ & $2 \cdot 934$ & $2 \cdot 958$ \\
\hline 55 & I month & 3.210 & $2 \cdot 608$ & $2 \cdot 598^{\star}$ \\
\hline 57 & I I days & $2 \cdot 873$ & $2 \cdot 547$ & $2.536^{\star}$ \\
\hline 57 & II days & $\mathrm{I} \cdot 646$ & $2 \cdot 180$ & $2 \cdot 190$ \\
\hline 62 & II days & 2.873 & $2 \cdot 500$ & \\
\hline 75 & $\frac{1}{2} \mathrm{hr}$ & Tap water & 2.559 & I. 420 (? \\
\hline & I hr. & & $2 \cdot 479$ & 2.477 \\
\hline
\end{tabular}

* Sample from nephroperitoneal sac. All others collected from the opening of the antennary glands. 
The contents of the different parts of the excretory system of three specimens of Leander were removed separately and their osmotic pressures estimated to find if significant differences could be discovered (Table IV). The method adopted was to dissect the prawns under the binocular microscope, after blood had been collected from the heart and urine from the opening of the antennary gland. The contents of the nephroperitoneal sac and the dorsal

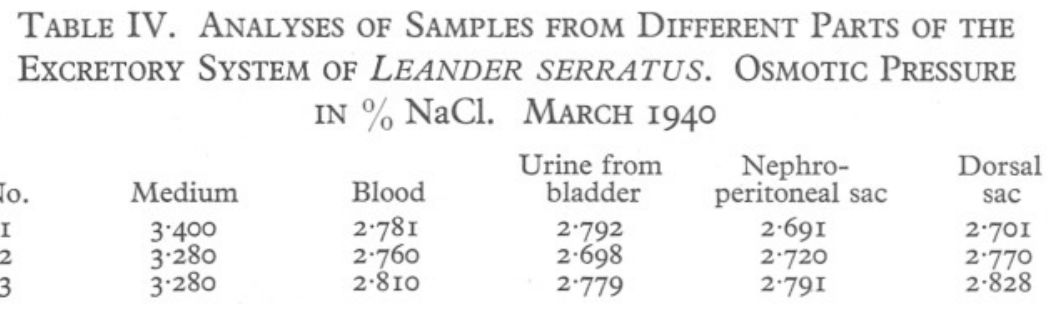

sac were collected in separate micropipettes. While reasonably pure samples could be obtained from the nephroperitoneal sac, the possibility of contamination with blood could not be completely ruled out in collecting from the dorsal sac, though every possible care was taken to make sure that the sample was pure. The values obtained are nearly identical with the blood except for slight variations which are well within the limits of experimental error. Similar analysis could not be carried out with Palaemonetes owing to its smaller size. The fact that there is isotonicity of urine with blood in Palaemonetes acclimatized to water of extremely low salinity, and the almost similar values obtained for the contents of the different parts of the green gland of Leander, would point to the conclusion that there is no mechanism for the production of urine hypotonic to blood in either of these prawns.

It may be mentioned here that, in addition to the antennal glands, the gills may be expected to have a marked excretory function as shown by the work of Mollitor (1937) on the crab Eriocheir.

\section{Osmotic Changes in Relation to Moulting}

Interesting osmotic changes in accordance with the moult cycle were discovered by Baumberger \& Olmsted (1928) in the crab Pachygrapsus crassipes. In sea water having a freezing-point depression of $-\mathrm{I} \cdot 975^{\circ} \mathrm{C}$. the tissue fluids of hard crabs had a $\Delta$ of $\mathrm{I} \cdot 327^{\circ}$, of pillans ${ }^{1} \mathrm{I} \cdot 893^{\circ}$, of hard crabs about to moult $2 \cdot 601^{\circ}$, and of newly moulted crabs $2 \cdot 193^{\circ}$. Thus the crabs are normally hypotonic to the extent of $-0.648^{\circ} \mathrm{C}$. when they are far from moult, but in most other stages of the moult cycle the blood is hypertonic to the external medium. It has been concluded that there is a large increase in blood concentration of crabs just before moult and that a considerable amount of

${ }^{1}$ A stage intervening between 'hard' and 'about to moult' crabs, characterized by cracks on the carapace. Also called 'peelers'. 
water is absorbed immediately after moult, which accounts for the reduction of osmotic pressure to normal. These changes have been confirmed in Callinectes sapidus (Baumberger \& Dill, I928) and in Carcinus maenas as regards water content (Robertson, I937). There is no reference in the literature to osmotic changes in Macrura as influenced by the moult. In Homarus it has recently been found that osmotic equilibrium is established soon after moulting (Lowndes \& Panikkar, I94I). The following observations are of interest, since in no stage of the moult cycle is Leander or Palaemonetes hypertonic or even isotonic to the environment, thus offering a striking contrast to the condition reported for Pachygrapsus crassipes.

In prawns it is by no means easy to judge the moult stages by appearance; nor is it possible to classify them into different moult groups as was done by Baumberger and Olmsted in Pachygrapsus. The prawns usually moult during the night and the moulting process itself is rapid; it was thus not possible to obtain a large number in which the time which had elapsed since the moult had been definitely ascertained. The procedure adopted was to keep isolated individuals under observation. The moulting has been described by Gurney (1923) in Leander longirostris and Nouvel (1933) in L. serratus, and I have little to add to these accounts. According to Nouvel the intermoult period varies from Io to 20 days-the interval being longest in large prawns. The intermoult period was much longer in the batch of prawns observed by me; in young prawns it varied from I 5 to 25 days, while the larger ones took about 30-35 days. In addition I have had under observation large prawns that had not moulted for 40-50 days.

Table V. Osmotic Changes of LEANDER SERRATUS in Relation to Moult Cycle. Temperature 6-I $2^{\circ} \mathrm{C}$.

\begin{tabular}{|c|c|c|c|c|}
\hline $\begin{array}{l}\text { Date } \\
\text { I940 }\end{array}$ & $\begin{array}{l}\text { Length } \\
\text { of prawn } \\
\text { mm. }\end{array}$ & Time after moult & $\begin{array}{c}\text { Osmotic } \\
\text { pressure } \\
\text { blood, } \\
\% \mathrm{NaCl}\end{array}$ & $\begin{array}{c}\text { Osmotic } \\
\text { pressure } \\
\text { medium, } \\
\% \mathrm{NaCl}\end{array}$ \\
\hline 2I. iii & 60 & $\frac{1}{2} \mathrm{hr}$ & 3.030 & 3.400 \\
\hline 22. iii & $5 I$ & $\mathrm{I} \mathrm{hr}$. & $2 \cdot 984$ & $3 \cdot 400$ \\
\hline I5. ii & $4 \mathrm{I}$ & $12 \mathrm{hr}$. & $2 \cdot 870$ & $3 \cdot 400$ \\
\hline I2. iii & 90 & I5 hr. & $2 \cdot 8 \mathrm{I} 5$ & 3.342 \\
\hline I4. ii & $5 \mathrm{I}$ & $24 \mathrm{hr}$. & $2 \cdot 820$ & 3.332 \\
\hline I4. ii & 54 & $24 \mathrm{hr}$. & 2.932 & 3.210 \\
\hline 23. iii & 60 & $25 \mathrm{hr}$. & 2.730 & 3.400 \\
\hline 23. iii & 95 & IO days & 2.635 & $3 \cdot 400$ \\
\hline 28. ii & 45 & 24 days & $2 \cdot 688$ & $3.34 \mathrm{I}$ \\
\hline 28. ii & IO2 & 38 days (ov. female) & 2.913 & $3.34 \mathrm{I}$ \\
\hline I4. $\mathrm{ii}$ & IOO & Far from moult & 2.990 & 3.332 \\
\hline I8. i & 94 & $\begin{array}{l}\text { Far from moult. New } \\
\text { moult imminent as } \\
\text { judged by appearance }\end{array}$ & $3 \cdot 046$ & $3 \cdot 246$ \\
\hline
\end{tabular}

The values given in Table $\mathrm{V}$ show that the prawns have a higher osmotic pressure than normal immediately after moult, but the concentration comes down to normal in about Io days' time. Expressed in terms of difference 


\section{TABLE VI. WATER CONTENT OF LEANDER SERRATUS}

Prawns from sea-water circulation except $\mathrm{I}$ and 2

\begin{tabular}{|c|c|c|c|c|c|c|}
\hline $\begin{array}{c}\text { No. } \\
\text { I }\end{array}$ & $\begin{array}{c}\text { Moult stage } \\
\text { I5 min. after moult }\end{array}$ & $\begin{array}{l}\text { Length } \\
\text { mm. } \\
55\end{array}$ & $\begin{array}{l}\text { Gross } \\
\text { weight } \\
\text { g. } \\
\mathrm{I} \cdot 4 \mathrm{I} 6\end{array}$ & $\begin{array}{c}\text { Dry wt. } \\
\text { g. } \\
0.307\end{array}$ & $\begin{array}{c}\% \\
\text { water } \\
-\end{array}$ & $\begin{array}{c}\% \text { water, } \\
\text { cast } \\
\text { included } \\
78 \cdot 32\end{array}$ \\
\hline 2 & $\begin{array}{l}\text { in Ca free sea water } \\
\frac{1}{2} \mathrm{hr} \text {. after moult in } \\
\text { art. sea water with } \\
\text { calcium }\end{array}$ & J & $2 \cdot 717$ & 0.564 & $80 \cdot 28$ & $79 \cdot 28$ \\
\hline 3 & $\frac{1}{2} \mathrm{hr}$. after moult & $\begin{array}{c}60 \\
\text { Moult alone }\end{array}$ & $\begin{array}{l}I \cdot I 80 \\
0.240\end{array}$ & $\begin{array}{l}0.242 \\
0.068\end{array}$ & $79 \cdot 5$ & $78 \cdot 17$ \\
\hline 4 & $2 \mathrm{hr}$. after moult & 59 & $I \cdot 120$ & 0.230 & $79 \cdot 46$ & $77 \cdot 98$ \\
\hline 5 & $3 \mathrm{hr}$. after moult & 60 & I. 348 & 0.278 & $79 \cdot 3^{8}$ & 二 \\
\hline $\begin{array}{l}6 \\
7\end{array}$ & $\begin{array}{l}\text { I day after moult } \\
4 \text { days after moult }\end{array}$ & $\begin{array}{r}60 \\
55 \\
\end{array}$ & $\begin{array}{l}I \cdot 240 \\
I \cdot I 66\end{array}$ & $\begin{array}{l}0.268 \\
0.287\end{array}$ & $\begin{array}{l}104 \\
75 \cdot 39\end{array}$ & $74 \cdot 57$ \\
\hline $\begin{array}{l}8 \\
9\end{array}$ & $\begin{array}{l}9 \text { days after moult } \\
30 \text { days after moult }\end{array}$ & $\begin{array}{c}\text { Moult alone } \\
95 \\
63\end{array}$ & $\begin{array}{l}0.234 \\
5.850 \\
1.630\end{array}$ & $\begin{array}{l}0.069 \\
1.370 \\
0.448\end{array}$ & $\begin{array}{l}76 \cdot 6 \\
72 \cdot 75\end{array}$ & 二 \\
\hline & $\begin{array}{l}\% \\
\text { Water } \\
\text { Solid }\end{array}$ & \multicolumn{2}{|c|}{$\begin{array}{c}\text { Before moult } \\
72 \cdot 7 \\
27 \cdot 3\end{array}$} & \multicolumn{2}{|c|}{$\begin{array}{c}\text { After mou } \\
79 \cdot 23 \\
20 \cdot 77\end{array}$} & \\
\hline
\end{tabular}

Amount of water in a prawn of dry weight $2.73 \mathrm{~g}$. after moult $=\frac{7 \cdot 923 \times 2.73}{2.077}=10.414 \mathrm{~g}$.

Therefore the amount of water absorbed $=10 \cdot 4 \mathrm{I} 4-7 \cdot 270=3 \cdot \mathrm{I} 44 \mathrm{~g}$.

Thus a prawn of fresh weight I g. absorbs $0.314 \mathrm{~g}$. of water during moult.

between internal and external media the osmotic deficit is least in newly moulted examples and the deficit grows as days elapse after the moult. I have not been able to establish any remarkable rise in osmotic pressure immediately before moult, but it may be that I have not been able to pick prawns that were actually in the throes of moulting. In two prawns far from moult a slight rise in osmotic pressure was observed, and this is probably an indication of the activity prior to moulting. While a slight rise from 2.6 to about $3.0 \% \mathrm{NaCl}$ is indicated, there is no evidence that the blood attains hypertonicity with the external medium, nor even isotonicity, for the blood of a prawn only ro min. after the moult gave a value of $3.00 \%$ with an appreciable osmotic deficit of $0.37 \% \mathrm{NaCl} .^{1}$ The general trend of osmotic changes in L. serratus during the moult cycle is similar to that of Pachygrapsus, with the difference that the range of variation is so limited that the hypotonicity of the blood is maintained in all stages of the moult cycle.

The exact mechanism whereby the increase in concentration is achieved prior to moult has not been satisfactorily explained in any crustacean. It would at least be partially explained by the conversion of accumulated glycogen into sugar as shown by Drilhon (1933) for Maia, though it should be admitted that the change in the sugar content of the blood observed in Callinectes (Baumberger \& Dill, I928) is insufficient to explain the whole osmotic rise. That the absorption of water is mainly responsible for bringing down the value to normal could be demonstrated by calculations based on

${ }^{1}$ This value is not included in Table V, only a single estimation having been made. 
changes in water content. In prawns immediately after moult, the water content is about $79 \%$; a slightly lower value of $78 \%$ is obtained if the cast skin is also included in the determination of gross and dry weights. On the other hand, prawns several days after moult have a water content of only about $72 \%$ (Table VI).

It is noteworthy in this connexion that Robertson (1937), working on Carcinus, found that a crab having a fresh weight of $50 \mathrm{~g}$. would absorb $35 \mathrm{~g}$. of water during moult. The corresponding figures for Maia squinado (Drach, 1936), Pachygrapsus crassipes and Hemigrapsus oregonensis (Olmsted \& Baumberger, 1923) are 58, 17 and $22 \mathrm{~g}$. respectively, while the corresponding value for Leander serratus is only I5.7 g. Lowndes \& Panikkar (194I) have found that Homarus of fresh weight Ioo g. absorbs about $47 \mathrm{~g}$. of water within less than 2 days after moulting. The difference between the amount of water absorbed by the stenohaline Maia and euryhaline Carcinus, and the much lower value for Pachygrapsus crassipes and Leander serratus would seem to be closely related to the differences in the permeability of the integument. We should expect a low permeability for animals that can maintain hypotonicity, and if the amount of water absorbed and the consequent osmotic changes taking place form an index of permeability, $L$. serratus would seem to be the least permeable of all the above-mentioned crustaceans.

\section{Table VII. Osmotic Changes of Palaemonetes varians}

\begin{tabular}{|c|c|c|c|c|}
\hline \multirow{2}{*}{$\begin{array}{l}\text { Date } \\
\text { I } 940\end{array}$} & \multirow{2}{*}{$\begin{array}{l}\text { Length } \\
\text { mm. }\end{array}$} & \multirow[b]{2}{*}{ Time after moult } & \multicolumn{2}{|c|}{ Osmotic pressure } \\
\hline & & & Blood & Medium \\
\hline \multirow[t]{2}{*}{ II. iii } & 40 & $6 \mathrm{hr}$. after moult & $2 \cdot 410$ & $3 \cdot 603$ \\
\hline & 40 & $\begin{array}{l}\text { Unmoulted for } 32 \text { days. } \\
\text { Same lot as above }\end{array}$ & $2 \cdot 382$ & 3.603 \\
\hline \multirow[t]{2}{*}{ IO. $\mathrm{iii}$} & 27 & I hr. after moult & $I \cdot 929$ & $I \cdot 000$ \\
\hline & 30 & $\begin{array}{l}\text { Unmoulted for a very } \\
\text { long time }\end{array}$ & $2 \cdot 034$ & $I \cdot 000$ \\
\hline
\end{tabular}

I have not been able to make many observations on moulting in Palaemonetes, but Table VII gives values of osmotic pressure observed immediately after moult in two prawns that have been in experimental media. The figures, as compared with the normal, indicate that a slight rise may be expected, but distinctly smaller than in Leander; the amount of water absorbed after moult may be correspondingly low.

\section{Change in Weight of Prawns in Diluted and Concentrated Media}

When a typical marine invertebrate is transferred to dilute sea water osmotic movements of water and salts take place resulting in a fall in the osmotic pressure of the internal medium. Direct determinations of osmotic pressure have shown that such a fall takes place in both Palaemonetes and Leander. If the dilution of blood is due to leakage of salts alone, there would be no appreciable difference in weight; but if it is caused by water entering the animal the 
weight of the animal should show a transitory increase. The changes in weight of $L$. serratus after transferring from sea water to $50 \%$ sea water are given in Figs. 6 and 7 which are self-explanatory. An increase in weight is observed in all the three instances, but the time taken to reach the maximum is different in different individuals owing probably to differences in size and in the moult cycle which has a considerable influence on permeability. An increase of 6-9 \% of original weight is noticed, but an increase above $6.0 \%$ would seem

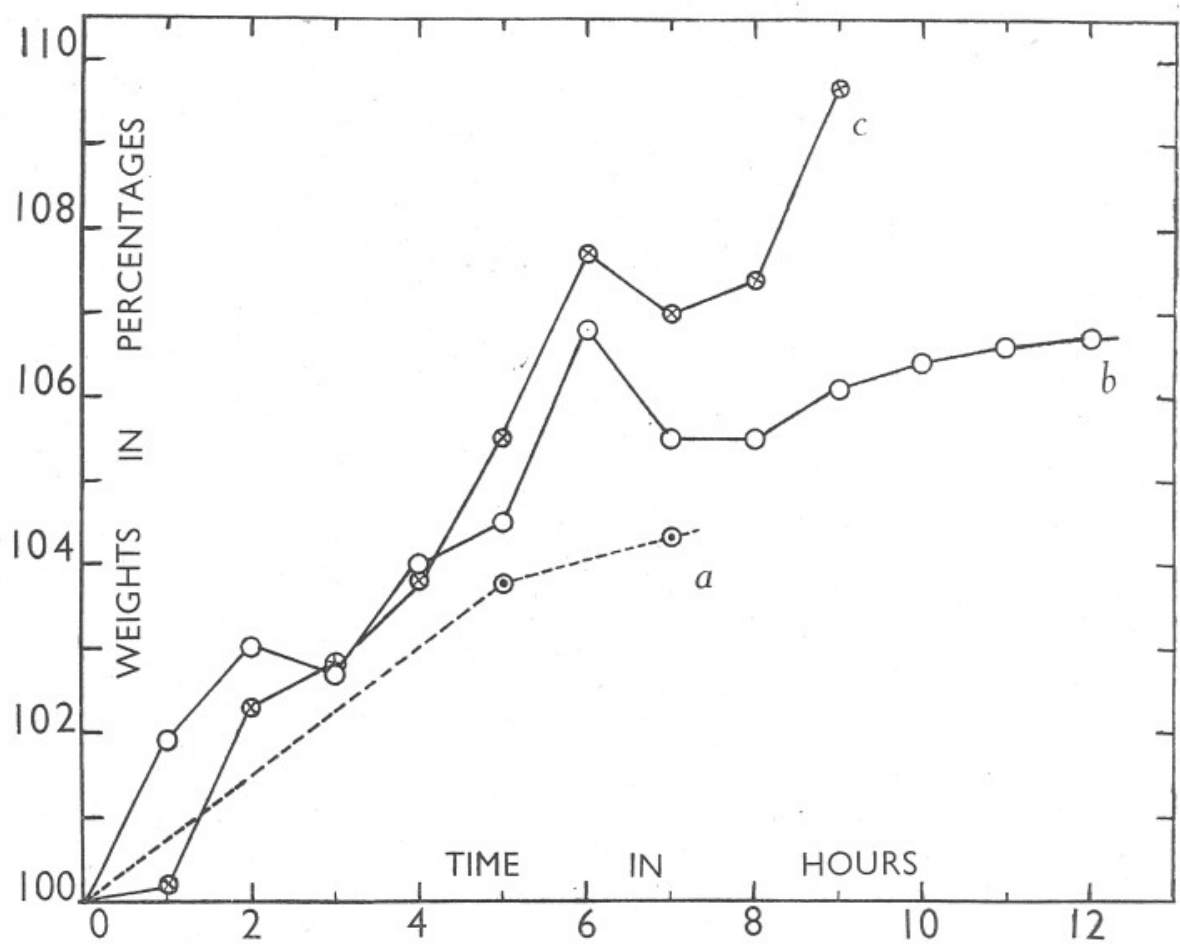

Fig. 6. Increase in weight of prawns in diluted media. Abscissae, time in hours; ordinates $\%$ of original weight. (a) Palaemonetes (dotted line), Io specimens weighted collectively after transfer from normal sea water to $33 \%$ sea water. (b) and (c) Leander serratus from sea water to $50 \%$ sea water, single individuals.

to be fatal, as shown by the fact that the individual that survived for a long time after direct transfer showed only a maximum of $6.0 \%$ and the values began to fall after about $25 \mathrm{hr}$. About 4 days were necessary for the prawn to show a constant weight, and this was about $2 \%$ higher than the original weight. Experiments with individual specimens of Palaemonetes were not possible owing to their smaller size and the consequent tendency for the errors to be magnified, but a definite increase in weight has been observed in this species as well (Fig. $6 a$ ). Ten Palaemonetes having an initial weight of $\mathrm{I} \cdot 86 \mathrm{~g}$. 
in sea water, where they had been living for months, showed an increase in weight of 0.07 g., i.e. nearly $3.8 \%$, after remaining for $5 \mathrm{hr}$. in $33 \%$ sea water. The increase was well over $4 \%$ after $7 \mathrm{hr}$.

Similar increase in weight has been noticed in many other marine crustaceans, such as Cancer pagurus (Schlieper, 1929), Portunus puber and $P$. depurator (Hukuda, I932); but Bethe (I930) failed to notice any appreciable increase in Carcinus maenas. In the mangrove crab, Heloecius cordiformis,

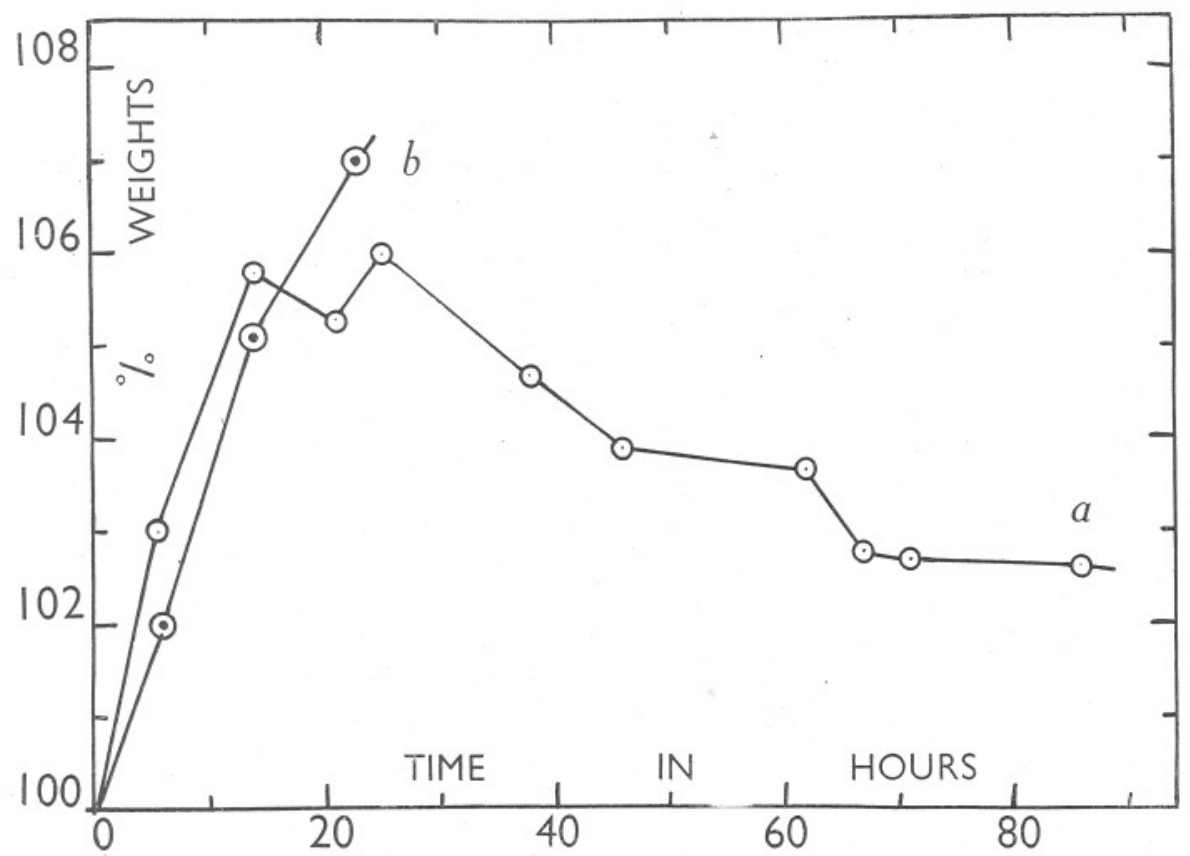

Fig. 7. Increase in weight of Leander serratus taken from sea water to $50 \%$ sea water. (a) Specimen far from moult, which survived the experiment. (b) Prawn 2 days after moult which died in $24 \mathrm{hr}$.

Dakin \& Edmonds (I93I) failed to observe any change in weight corresponding to changes in the medium. In the brackish-water Gammarus duebeni and the freshwater Gammarus pulex, Beadle \& Cragg (I940 a) observed no appreciable change in weight; they conclude that in both these species changes in the osmotic pressure of the blood are due to salt and not to water movements. The changes in weight observed in Leander and Palaemonetes indicate definitely that the gills of both the species are permeable to water and that the dilution of the blood consequent on sudden transfer to dilute media is mainly brought about by the water that enters. A few hours after transfer a slight swelling and a high hydrostatic pressure of blood may be noticed in Leander. In the crabs studied by Hukuda a change of only about $4 \%$ of weight was noticed and, by comparing with calculated figures assuming semipermeability, 
the weight increase due to entry of water was shown to be insufficient to account for the fall in osmotic pressure of blood; he was therefore able to demonstrate the passage of an appreciable amount of salt to the exterior. Similar calculation with Leander would show that the amount of water that enters must be to a large extent responsible for the dilution of the blood, since the extent of dilution taking place is small owing to the low normal value for blood. The escape of salts to the exterior would seem to be inconsiderable at least in moderately dilute sea water, but it certainly takes place when the medium is very dilute.

When prawns are transferred from dilute to concentrated sea water there is a corresponding fall in weight, giving clear evidence of the escape of water to the exterior. The results obtained in experiments with Palaemonetes varians and Leander serratus are given in Fig. 8.

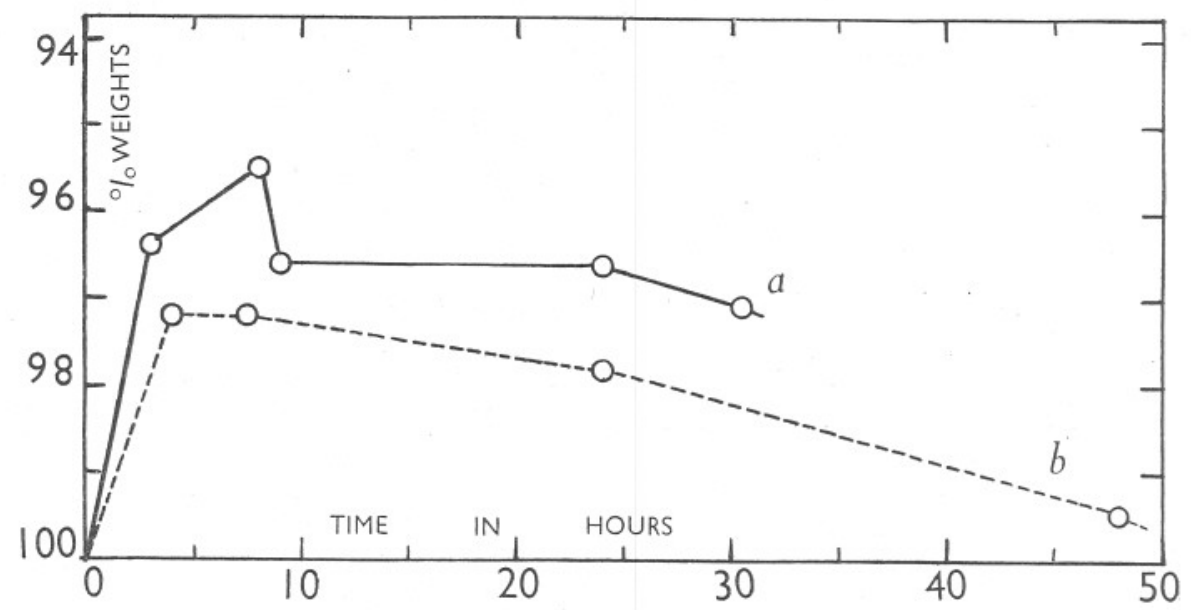

Fig. 8. Decrease in weight of Palaemonetes and Leander when taken to concentrated media.

(a) Leander serratus acclimatized to $50 \%$ sea water transferred to normal sea water. (b) $P$. varians acclimatized to Io \% sea water transferred to normal sea water; Io specimens used collectively. (20. v. 40.)

\section{Permeability of the Gills}

In Crustacea the integument has a very low permeability, being heavily impregnated with chitin and protected by cuticle. The only possible surface through which water and salts may freely diffuse into the body of the animal is that afforded by the gills. The following experiments were performed to ascertain the extent to which the gills of Leander and Palaemonetes are permeable.

A strong solution of methylene blue was dialysed into sea water kept in a jar until the sea water was rich blue and opaque. Specimens of Leander serratus, Crangon vulgaris and Carcinus maenas were transferred to the jar 
from the sea-water tanks. The Leander and Crangon chosen were approximately of the same size. The animals were removed at the end of half an hour, dissected, and the gills examined under the microscope. Of the preparations from the three species, the presence of methylene blue in the cells of the gill plates could easily be observed in Crangon and Carcinus, whereas no trace of the dye could be detected in the cells of Leander serratus. When the animals were left for about an hour, the gills of Crangon and Carcinus assumed a rich blue colour distinguishable even with the naked eye. In contrast to this, Leander, even if left for hours, failed to absorb the dye; the gills became faint blue after several hours, but this was owing to the presence of the dye between the gills and not in the gill cells proper.

The same experiment was performed with a methylene blue solution made in distilled water to which a small quantity of sea water was later added. This was necessary to prevent the early death of the experimental animals which would otherwise result. The osmotic pressure of this very dilute solution was $0.06 \% \mathrm{NaCl}$. The results were similar to those of the previous experiment. The gills of Crangon and Carcinus took the dye in a very short time, the former being the first to show its presence. Even after $7 \mathrm{hr}$. of immersion the gills of Leander were colourless and the dye did not penetrate even I hr. after the death of the experimental animal.

Experiments with Palaemonetes varians gave the same results. The behaviour of the animal was also observed with methylene blue dissolved in concentrated sea water. The use of methylene blue is open to criticism owing to the fact that it may have been reduced after penetration (vide Gray, I93I). If an acidic dye like vital red is substituted, the dye has been observed to penetrate in Leander after prolonged immersion, while about half an hour is enough for Crangon and Carcinus. In regard to Palaemonetes the amount of vital red that penetrates (if any does) is extremely small, as judged by the examination of the gills of prawns appropriately treated. With a quick penetrating dye like neutral red, the gills of living Crangon are stained in a few minutes, while even after half an hour only a slight trace of the dye could be seen in Leander. These observations, though of a preliminary character, demonstrate that in Leander and Palaemonetes the permeability of the gills is very low as compared with the marine Crangon and the euryhaline Carcinus, or at any rate that the membrane properties of the palaemonid gills are different from that of the others.

\section{WATER-DRINKING HabITS OF PRAWNS}

If a prawn is losing water by diffusion owing to the higher osmotic pressure of the external medium, one of the ways of making up for the water loss is for it to drink water. The technique employed to verify this water-drinking habit was essentially the same as that of Homer Smith (I930) who used phenol red as a suitable indicator. In addition to this dye, I have also employed vital red 
and brom-cresol green. Concentrated solutions of these dyes were added in small quantities to jars containing prawns in experimental media, and the animals were examined after suitable intervals to find if the dye could be detected in the alimentary canal. Unlike the teleosts, the dyes seldom reach the hind-gut or even the posterior half of the mid-gut, since the absorption seems to take place in the hepatopancreas and part of the fore-gut. One difficulty encountered in this connexion was the presence of pigmented cells in the hepatopancreas which are themselves subject to colour variations. By careful examination of teased tissues under the microscope it was, however, possible to distinguish the foreign dye as distinct from the natural pigmentation.

Both Palaemonetes varians and Leander serratus have been observed to drink the external medium, especially when the latter happens to be sea water or concentrated sea water. It must be mentioned, however, that even when the external medium is hypotonic they have been observed to take in water as judged by the presence of dyes inside them. The results obtained have been on the whole erratic. While (after proper treatment for $p \mathrm{H}$ differences) the dye became detectable in the hepatopancreas of some specimens in a few hours, in others I have not been able to observe the dyes even after I4 $\mathrm{hr}$. In one set of experiments when solutions of the same concentration were used as the external media (sea water) for both the species, it was found that the dye was seen in Palaemonetes in I day while it took 4 days in Leander. Experiments in sealing the mouth and preventing the entry of sea water were not successful, since the oral appendages are always at work and remove any foreign body near the mouth.

The fact that water drinking may occur in both hyper- and hypotonic media and the wide divergence in results obtained with different individuals in the same medium seem to indicate that it is not an essential part of the osmoregulatory mechanism. It is probable that water gets into the alimentary canal when the prawns feed or when they attempt to search for food. When directly transferred to very concentrated media there is some evidence from osmotic changes to show that salt water is taken in from the surroundings (see p. 326).

\section{Discussion}

\section{Mechanism of Osmoregulation}

If an animal is able to maintain a lower osmotic pressure of the blood than the sea water in which it lives, it must either be completely impermeable to water and salts or it must be doing continuous osmotic work. Complete impermeability is not practicable in marine animals that depend upon the external medium for their essential supply of oxygen which has to diffuse through the gills. If, on the other hand, salts from the external medium penetrate the integument and water escapes in accordance with the laws of osmosis, the animal has first of all to make up for the loss of water it sustains 
and, secondly, it must get rid of salts to maintain the osmotic deficiency. The mechanisms possible are: (I) by producing a concentrated and markedly hypertonic urine, the animal can achieve elimination of excess of salts, and this may be further elaborated by the development of a special water reabsorbing mechanism; (2) it may drink sea water from time to time and thus make up for the loss of water and simultaneously excrete the excess of salt from the body, not necessarily through the agency of the kidney; or (3) the animal may absorb water from the surrounding sea water but not salt. The capacity to produce hypertonic urine has so far been observed only in vertebrates which have become terrestrial in habits, under conditions where the problem of conserving water is of paramount importance; none of the primarily aquatic organisms is known to possess it. In the marine teleosts, which have an osmotic pressure about one-third that of sea water, it has been demonstrated by Homer Smith (I930) and Keys (I93I, I933) that regulation is effected by the drinking of sea water and excretion of salts by the gills. We have seen that in Leander serratus and Palaemonetes varians the urine is isotonic with the blood whether the external medium is of extremely low or high salinity. The fact that the animals drink sea water and do this much more when in hypertonic media might suggest at once that the regulatory mechanism of palaemonid prawns is probably similar to that of marine teleosts. But this explanation alone would be insufficient to account for the osmotic independence of these prawns to wide variations in environment, and the ability, at least in Palaemonetes, to live in abnormally high concentrations of sea water which would be lethal to most marine animals - an ability comparable only with the classical instance of the brine shrimp Artemia. It seems likely that active water transport from outside to inside takes place in order to maintain hypotonicity in sea water in the same way as active salt absorption takes place in dilute sea water.

The total osmotic pressure curves of Palaemonetes and Leander indicate beyond doubt the homoiosmotic behaviour which they exhibit when their media are changed; this power is markedly developed in the former and partially lost in the latter. Within a range of nearly $5.0 \% \mathrm{NaCl}$ in its external medium the blood of Palaemonetes is affected only to the extent of about $0.8-\mathrm{I} .0 \% \mathrm{NaCl}$. The range of variation is much greater in Leander, but even here the blood is little affected by the dilution of the environment up to about $2.5 \% \mathrm{NaCl}$; and it is probably reasonable to assume that under no circumstances is $L$. serratus subjected to changes in environment below this range under natural conditions. Palaemonetes, on the other hand, inhabits regions subject to wide fluctuations in salinity, not only seasonal but also tidal, the ditches in which it lives being liable to evaporation and to inundation by sea or river water. Leander squilla shows an intermediate condition which is what one would expect from its habits. But while the difference in homoiosmotic behaviour is consistent with the habits of these prawns, it does not enable us to judge how a new physiological ability has been acquired in one 
genus that is anatomically so similar to another, or how the palaemonid prawns have acquired an osmotic behaviour so different from other marine prawns.

When Palaemonetes is in water of extremely low salinity it has an osmotic pressure equivalent to about $2 \cdot 0 \% \mathrm{NaCl}$ under natural conditions and about I. $8 \% \mathrm{NaCl}$ under experimental conditions. If the curve be projected to the freshwater limit the value cannot be below $\mathrm{I} \cdot 7 \%$, and under conditions in which the species has become naturally acclimatized to fresh water ${ }^{1}$ it is likely that the value is even slightly higher. This is no doubt much higher than the values of the osmotic pressure of most other freshwater Crustacea. The crayfishes Potamobius and Cambarus have blood with freezing-noint depressions of about $-0.8^{\circ} \mathrm{C}$. (about $\mathrm{I} \cdot 37 \% \mathrm{NaCl}$ ) and $-0.65^{\circ} \mathrm{C}$. (about I. II \% NaCl) respectively (Duval, I925; Schlieper, I935; Lienemann, I938), and freshwater insects such as the mosquito (Aedes argenteus, Wigglesworth, I933) and chironomid larvae have lower values (Harnisch, I934; Koch, I938), while freshwater branchiopods (Daphnia, Fritzsche, I9I7; Chirocephalus, Panikkar, I94I) have osmotic pressures lower than in any other crustacean. In these freshwater forms there is a regular osmotic stream of water entering the body through the gills and escaping through the excretory system. In Potamobius, Peters (I935) has conclusively shown that the danger of loss of salts through the discharge of large amounts of urine is overcome by the salt reabsorbing mechanism resident in the nephridial canals, which makes the final urine extremely hypotonic to the blood. In the same way as freshwater organisms depend upon an osmotic stream of water for copious urine production, the marine teleosts depend upon the continuous drinking of sea water to cope with the elimination of salts through the gills. If the question of osmotic regulation is entirely dependent upon the continuous entry of water or salts through a semi-permeable membrane and the consequent elimination of water or excretion of salts, it would hardly be possible for animals to survive sudden changes in environment, since equally sudden reversal of physiological processes could seldom happen. It becomes evident, therefore, that the ability to control the exit and entrance of substances in the body of aquatic animals is an integral part of the regulatory mechanism. It may be achieved by different methods, as by the development of a keratinous waterproof coat in the majority of teleosts, the secretion of mucus in the eels (Duval, I925; Keys, 1933), or by the development of an almost impermeable cuticle in arthropods. The factor of salt retention, recently emphasized by Beadle $\&$ Cragg (I940b), would seem to be the result of the low permeability of the integument.

\section{Permeability of the Integument: Water and Ion Transport}

It is well known that the crustacean integument has a low degree of permeability except in the region of the gills, where exchange of substances can

1 The value may be well below this in warmer latitudes (vide Panikkar, $1940 b$ ) as shown by Vialli's (1925) results. 
take place in both directions. Different degrees of permeability have been noted by previous authors. In most marine Decapoda, Bethe (I929, I930) has shown an almost indiscriminate permeability (of the gills) to water and ions; but these are forms in which the external and internal media are isoosmotic. The ionic composition of the blood of these animals and that of sea water need not, however, be the same as shown by Bethe \& Berger (I93I) and by the recent analyses of Robertson (I939), but, in any case, a fairly constant ionic equilibrium is maintained. The extent of permeability is different even among stenohaline Crustacea; low permeability has been noticed in animals that show euryhaline tendencies, while true euryhaline animals are even much less permeable. Carcinus, for example, is less permeable to ions in both directions than marine crabs like Portunus and Hyas (Nagel, I934); however, it is permeable to both water and salts as shown by the dilution curves of Margaria (I93I), Bateman's (I933) conclusion that the gill membrane is almost impermeable to water being incorrect (Krogh, I939; Webb, I940). In the freshwater Cambarus bartoni, Maluf (1937) has shown that the gills are permeable to water but not to electrolytes, but in a later $\operatorname{paper}^{1}$ (1939b) he admits that chlorides could pass through in both directions. The gills of Eriocheir sinensis are permeable to water and to substances like chloride and ammonia (Krogh, I939). There is possibly no aquatic crustacean the gills of which are not permeable to water, for even the brine shrimp Artemia is permeable as indicated by experiments with heavy water (Krogh, I939). The experiments made on the permeability of the gills of Leander and Palaemonetes, though only of a qualitative nature, show that the gills are much less permeable than in marine or even euryhaline animals like Carcinus. Changes in osmotic pressure and water content during the moult cycle also support this conclusion. The condition observed in these prawns is comparable to that of Eriocheir and possibly Cambarus; definite permeability in both directions exists for water and ions. However, the amount of water that enters the prawns when they are in osmotically inferior surroundings must be much less than that observed in freshwater Crustacea with salt-reabsorbing mechanism, since large-scale urine production will not be consistent with conservation of salts. Loss of water from the tissues when the prawns are in hypertonic media is inevitable, though the amount of water lost is not considerable owing to low permeability. If the loss of water is great, as for example in very concentrated media, it is probably made up by taking in sea water through the alimentary canal; but there remains the question of excretion of salts, the site of which has not been definitely proved, though circumstantial evidence seems to point to the gills.

The alternative possibility is an active transport of water (but not salts) into the body from the surrounding sea water. The osmotic work required to absorb water against an osmotic gradient would be of about the same order as

1 Based on abstract in Biological Abstracts. The original paper was not available for consultation owing to the war. 
that required for secreting salts to osmotically superior surroundings. It has to be mentioned, however, that active transport of water alone through a living membrane and against an osmotic gradient has not been demonstrated in any marine animal. Studying the ionic regulation of Carcinus, Webb (I940) brings circumstantial evidence in favour of water transport. That absorption of water takes place in Crustacea after moult is well known from the results of Baumberger \& Olmsted (1928), Robertson (1937) and Drach (1939). In Leander, changes in water content and osmotic pressure during the moult cycle indicate the selective absorption of water immediately after moult so as to account for a rise of almost $5 \%$ (cast included) in water content and a fall in osmotic pressure of about $0.2 \% \mathrm{NaCl}$. If water and salts were absorbed without preference we should find a rise in the concentration of the blood after moult and not the gradual reduction actually observed, assuming, of course, that the excretory function remains normal. Since the highest osmotic pressure registered $(3.030 \% \mathrm{NaCl})$ is well below the value of sea water, this absorption takes place against an osmotic gradient and is, I think, sufficient proof of the ability of water transport in Leander, at least soon after moult. It is quite probable, therefore, that this capacity is not completely lost even during intermoult periods, and that active transport of water, probably across the gill membrane, plays a significant part in osmoregulation. Though technical difficulties in demonstrating this have not been completely overcome, it is hoped that analysis of ionic regulation will throw some light on this problem, for osmoregulation is mainly the result of the intensification of the processes at work in ionic regulation (Pantin, I93I; Webb, I940).

The concept of salt transport, presumed by Schlieper (1929, I935), conclusively shown in Carcinus by Nagel (1934) and explained on the basis of active ion absorption demonstrated by Krogh and his collaborators, accounts for the ability of many euryhaline and freshwater animals to maintain a high osmotic concentration. Intake of salts by Palaemonetes and Leander has been demonstrated. Though the possibility of at least some of the salts being absorbed through the gut cannot be ruled out, the quantity thus absorbed must necessarily be small owing to the fact that it would be unfavourable to the animal from the point of view of water economy. The only other place where salt assimilation can take place is the gills, and in view of the results obtained by Krogh (1939) and Koch (1934) the gills are presumably the site of ion transport in prawns.

\section{Role of the Gills in Osmoregulation}

From what has been said above, it will be clear that the gills of palaemonid prawns are the most vital organs in osmoregulation, especially in view of the relatively unimportant role played by the renal organs. They should have a low permeability to reduce the amount of osmotic work to be done when prawns are in hypotonic as well as in hypertonic media; they have to discharge salts to the exterior when the medium is hypertonic or alternatively transport 
water into the body from the surroundings, and they have to perform the function of ion assimilation when the medium is hypotonic. Confirmation on these points is possible only after the direct histochemical observations on gills, which are being made, have been completed.

The following facts in regard to the structure of the gills of Palaemoninae are relevant in this connexion. Allen (1892a), in his account of the minute structure of the gills of Palaemonetes varians, describes the occurrence of numerous reticulous and clear glands on the axis of the gill. Cuénot (I895), who observed similar glands in certain other Crustacea, considered them to have the function of mucus secretion; but Yonge (1932), from a comparative study of similar structures, concluded that these tegumental glands are responsible for the secretion of the cuticle of arthropods. He finds the cuticle thickest where the glands are most numerous. Considering the fact that it is the cuticle that reduces the permeability of chitin, the presence of a large number of such glands on the gills is suggestive of the role they play in securing the low permeability of these prawns. In the freshwater Palaemon, Patwardhan (I937) mentions that the axis is protected by a thick layer of cuticle and that the gill plate itself is covered by a double layer of cuticle. From an examination of the gills of Carcinus, Maia, Hyas and Eriocheir, Webb (I940) concludes, however, that the cuticle is of little significance in controlling permeability and that the control is really exercised by the nature of the epithelium. That the gills have an excretory function is suggested by the fact that dyes injected into the animal are collected by certain cells lining the blood vessels of the gills ${ }^{1}$ (Kowalevsky, I889), and Cuénot (I895) has observed that their behaviour is almost identical to that of cells of the end-sac. According to Allen these cells surround the veins and possess vacuoles with excretory concrements. Whether or not they have a chloride-secreting function cannot be asserted at present, but they are definite evidence of active excretory processes taking place in the gills. In regard to ion absorption, Koch (I934) has demonstrated the curious affinity for silver salts of certain cells found in the branchiostegites of Leander serratus and Palaemonetes varians, and he suggests from a comparative study of similar cells in other arthropods that this property is evidence of active ion absorption taking place in the branchial epithelium.

\section{Role of the Kidneys in Osmoregulation}

The mechanisms employed to achieve osmotic independence of the surrounding medium are quantitatively and qualitatively different in the different groups of animals which have succeeded in establishing themselves in fresh water. Those which have developed the capacity to produce hypotonic urine have in general the lowest concentration of blood, in contrast to those producing blood isotonic urine which, though found in fresh water, have a high osmotic concentration of blood. Maluf (1938), reviewing the question of

1 I have repeated these experiments and obtained similar results. 
excretion in the Arthropoda, concludes that the nitrogenous wastes, which in Crustacea consist mostly of ammonia (Delaunay, I93I), are probably secreted into the lumen of the antennal kidneys by the cells of the labyrinth. That the actual filtration of water and crystalloids from the blood takes place first of all into the coelomic sac is evident from the work of Picken (1936) and Peters (1935). The morphological differences between the antennal glands of the marine Homarus and the freshwater Potamobius emphasized by Peters, and the significant changes in chloride content which he observed in the different parts of the green gland, have established conclusively that the nephridial canal of the freshwater crayfish is mainly concerned with the reabsorption of salts from the urine as it flows down from the labyrinth into the bladder. It has been found that the nephridial organs are usually provided with longer nephridial canals in the freshwater as compared with marine Crustacea, as shown by Schwabe (1933) in the freshwater Gammarus pulex and the marine Gammarus locusta. Exceptions to this rule have been found in crabs, such as Eriocheir sinensis and Potamon ${ }^{1}$ fluviatilis, which though capable of living in fresh water have excretory organs similar to those of marine crabs (Schlieper, I929; Schlieper \& Herrmann, I930). To these must now be added the palaemonid prawns which, though capable of penetrating into fresh water, do not have an excretory system specially modified for the purpose. The blood-isotonic urine in Leander serratus and Palaemonetes varians is not surprising when we consider the structure of the excretory organs, for neither has a urinary canal. Both the end-sac and the labyrinth are small and compact and very near the external orifice of the bladder. The structure of the bladder epithelium precludes the possibility of any active reabsorption taking place there. However, there is a distinctive feature in the excretory system-the enormous renal or nephroperitoneal sac which absorbs dyes injected into the animal and necessarily performs a certain amount of active excretion (Weldon, I89I; Marchal, I892). From the fact that the walls of the sac are richly provided with blood vessels it would appear that a certain amount of filtration may possibly also take place there. Though the essential lay-out of the excretory systems in Leander and Palaemonetes is similar to that of the marine prawns Pandalus, Hippolyte and the shrimp Crangon (Weldon), they are enormously developed and fused to form a large storehouse of urinary fluid. This would seem to be advantageous in the production of large amounts of urine, since the rate of urine production is likely to be different when the prawns are in different media. Schwabe (1933), who examined sections of Palaemonetes varians microgenitor (brackish water) and macrogenitor (fresh water), could not discover any noticeable structural difference in the excretory organs of the two varieties. Similarly the description of the excretory organs of the freshwater Palaemon given by Patwardhan (1937) is essentially the same as that of Leander. On anatomical and osmotic grounds the evidence available is that adaptation to fresh water in the Palaemoninae has not been accompanied by

${ }^{1}$ Formerly known as Telphusa. 
the development of a salt reabsorbing part of the nephridium and the ability to produce urine hypotonic to the blood. It is probably this very fact which has enabled the freshwater palaemonids to tolerate salt water.

\section{Evolutionary Significance of the Osmotic Behaviour of the Palaemoninae}

The osmotic behaviour of Palaemonetes varians, Leander serratus and $L$. squilla appears to be of great significance when viewed in relation to the habits and distribution of the group to which they belong. The family Palaemonidae includes four subfamilies, of which the Pontoniinae are marine, the Desmocaridinae and Typhlocaridinae are fluviatile, while the Palaemoninae include the following seven genera with habitats ranging from fresh to salt water:

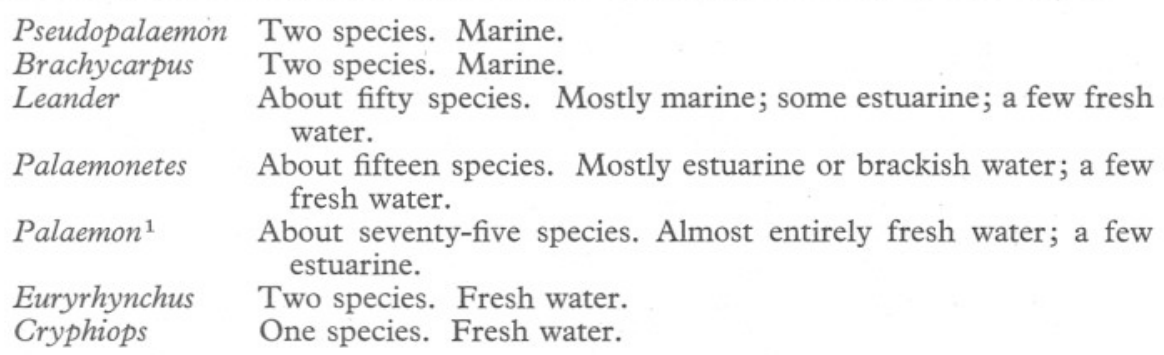

The genera of the subfamily have been discussed in some detail by Kemp (1925). Leaving out of consideration the exclusively marine and freshwater genera, we find that species of Leander, Palaemonetes and Palaemon occur both in salt and fresh water. Leander is mainly marine, but a good many species are estuarine; at least two occur only in fresh or brackish water (L. gardineri and $L$. fluminicola); not less than five species are known only from fresh water (L. potitinga, L. cubensis, L. modestus, L. capensis and L. annandalei); others, like $L$. concinnus and $L$. paucidens, seem to be indifferent to the salinity of the medium. Kemp observed L. fluminicola nearly 700 miles up the Ganges in India. Of the four species of Leander found on the English coasts, L. longirostris is known to ascend many miles up rivers (Gurney, I923; Schnakenbeck, 1933). L. serratus is able to survive in brackish water for short periods and L. squilla is often observed in brackish water, though both are essentially marine species confined to the littoral zone. L. adspersus is a marine and brackish-water species.

Palaemonetes, though found only in fresh and brackish water under natural conditions, includes at least two species that can thrive in sea water. $P$. vulgaris is mainly an estuarine species but is also known from the sea on the American coast (Faxon, I879). As mentioned before, there are few, if any, valid records of $P$. varians from the sea, but the prawn has been observed to live for many months and to breed in the sea-water tanks of the Plymouth Laboratory.

${ }^{1}$ Inclusive of the species referred by some carcinologists to the genera Macrobrachium and Bithynis. 
Palaemon is an essentially freshwater genus, but a few species, such as $P$. rudis, $P$. carcinus, $P$. malcolmsoni and $P$. lamarrei, are known to migrate into brackish water during breeding periods (Kemp, I9I5; Panikkar, I937); the last-mentioned species is particularly tolerant to salt water and has been noticed in true brackish-water habitats (Panikkar \& Aiyar, 1937). Menon (1938) has found the larvae of $P$. rudis and $P$. carcinus in brackish water.

It should be mentioned in this connexion that there are few reliable characters to distinguish Palaemon from Leander. While the main difference between the two is the presence of the hepatic spine in Palaemon and of the branchiostegal in Leander, there are two species (L. potamiscus and L. fluminicola) which, though obviously Leander, are without the branchiostegal spine, while in Palaemon hildebrandti the hepatic spine is sometimes absent; P. mirabilis, though technically a Palaemon, is remarkably like some species of Leander (Kemp, I925). The specific characters of some of these species of Palaemon and Leander so overlap that their diagnosis is extremely difficult even for the specialist. Kemp, reviewing the species, considers that the genus Palaemon is probably polyphyletic in origin. The same view is held in regard to Palaemonetes (Kemp, I925, p. 315), whose resemblance to certain groups of species of Leander in the adult as well as in the developmental stages is so marked that Gurney (1939) suggests there is nothing in the development of Palaemonetes to justify its separation from the genus Leander.

The discovery of osmotic independence in a purely marine species of Leander and of a highly developed homoiosmotic behaviour in L. squilla and Palaemonetes varians suggests that all the prawns known from varied habitats, included in the genera Palaemon, Leander and Palaemonetes, possess a welldeveloped mechanism of osmoregulation. Osmotic independence must naturally exist in all the freshwater genera of the Palaemoninae-Palaemon, Euryrhynchus and Cryphiops. The fact that all species of Palaemonetes are found either in fresh water or in brackish water, considered in the light of the behaviour of $P$. varians, would indicate that relative osmotic independence is probably to be found in all the members of this genus. It is to be expected that a similar independence will be found in all the freshwater and at least all true brackish-water species of Leander. In regard to marine Leander, direct evidence has been obtained only in L. serratus and $L$. squilla, but I consider that osmotic independence is likely to occur in L. longirostris, as judged by its migratory movements, and in many Indian species, such as L. styliferus, which I have often found in brackish and sea water. The degree of hypotonicity when in sea water is bound to be varied; it may even be completely absent when the prawns are in normal sea water and may become apparent only in concentrated sea water as observed in Eriocheir sinensis (Conklin \& Krogh, I938). It would be of the utmost interest to know the osmotic behaviour of palaemonid prawns from different habitats in different parts of the world, for we might then secure data on their physiological adaptation which would throw light on their evolutionary history. 
If an animal shows a high degree of osmotic independence relative to the external medium, especially if it involves ability to maintain hypotonicity, it is reasonable to consider that the animal must at some time in its evolutionary history have inhabited fresh water (Pantin, I93I; Baldwin, I937), for such a mechanism would never have been needed for a purely marine life. The penetration of most marine animals into brackish water is closely associated with the development of osmoregulatory powers; but we find in them only an ability to maintain hypertonicity when the external medium is dilute sea water. This is brought about by decreased permeability to water and salts and active transport of ions from the outside to the inside. Thus, animals like Carcinus maenas can survive in brackish water of very low salinity, and maintain a high osmotic concentration of blood (Schlieper, I930, and others), but isotonicity is established the moment they are taken back to sea water (Frédéricq, I904; Duval, I925). A further development of this ability to maintain hypertonicity enables a brackish-water animal to penetrate into fresh water. The adjustments required would either be increased ability to assimilate ions and a low permeability to water, or the development of renal saltreabsorbing mechanism whereby loss of salts would be reduced to a minimum. We have found that in Palaemonetes acclimatization to fresh water has been brought about by the former method without any undue specialization of the excretory system, and it is by virtue of this that the prawn is able to live in external media of a wide range of concentration, a feature which it shares with many other Palaemoninae.

Two theories are possible to account for the osmotic independence shown by Leander serratus and L. squilla. One is that they have been derived from prawns that have been established in fresh water and developed a high degree of osmotic regulation, but that for some reason they began to penetrate back into brackish water and then into the sea. In the same way that a low permeability was advantageous in reducing the entry of water into the body of prawns when in fresh water, it was helpful in reducing the loss of water when the medium became hypertonic. The second possibility is that the presentday species of Palaemonetes, Palaemon and Leander are descendants of prawns which left the sea for life in inlets that eventually became land-locked and were thus subject to increase in salinity; in consequence they were obliged to develop a mechanism for maintaining hypotonicity and a low permeability. An argument against the latter theory is that these genera are world-wide in their distribution, and it is unlikely that these special conditions could have been so widespread. Both possibilities may have occurred and may account for the suggested polyphyletic nature of the genera in question. I consider the first explanation the more plausible in regard to L. serratus and L. squilla, since, if it were otherwise, the optimum value of total osmotic pressure would certainly have been higher than 2.8 and $2.6 \% \mathrm{NaCl}$. Whether all Leander have had a freshwater ancestry or not cannot be asserted until the numerous other marine species have been subjected to close study. Investigations on 
Brachycarpus and Pseudopalaemon would be of exceptional value, for if they are stenohaline they may represent forms which have not developed osmoregulatory powers in their history; on the other hand, if they have an osmoregulatory behaviour comparable to that of Leander, they would represent forms that have become secondarily marine in recent times.

The biochemical aspect of adaptation to fresh water emphasized by Needham (1930, 1937) throws some light on the question of the recolonization of salt water suggested in L. serratus and L. squilla. One important condition to be fulfilled if an animal is to establish itself in fresh water is that it should provide, within its egg, enough ash for complete development instead of having to depend upon the environment for inorganic substances essential for the organization of the embryo. The provision of ash in the embryo is therefore as necessary to enable a species to establish itself in fresh water as osmoregulation is to enable the individual to live in fresh water. It is well known that there are many animals which though they occur in fresh water have not overcome this embryonic obstacle, and are thus obliged to migrate into salt water in which alone their eggs can develop. This migration may also be necessitated by the absence or inefficiency of the osmoregulatory mechanism in the embryo, the mechanism, however, attaining its full functional significance in the adults which can therefore migrate into fresh water. Gurney (1923) found that in L. longirostris the eggs can develop only in salt water in spite of the adults being quite at home in fresh water.

It is well known that a large egg and a reduced or suppressed larval development is a characteristic of many freshwater animals, but the information we possess on this point in the Palaemoninae is widely scattered and not as precise as could be desired. In the crayfishes, the Astacidae and Parastacidae, the eggs are always large and the young are liberated in a form closely resembling the parents. In Palaemon, some species, such as P. lamarrei, have large eggs and a reduced development (Henderson \& Matthai, I9Io), while in others the eggs are small and there is no doubt a long series of larval stages. Some species with small eggs, such as $P$. carcinus, $P$. malcolmson $i$ and $P$. rudis, are known to migrate from fresh water to brackish water in order to liberate their young, and from this circumstance it is to be concluded that the osmoregulatory mechanism is absent or inefficient in the early stages but becomes functional after growth has proceeded and the young prawns are ready to ascend the rivers. In all probability, however, it would be incorrect to say that all species of Palaemon with small eggs must have access to brackish water during the breeding season; for it is likely that small-egged species are to be found in localities so far inland that regular access to the coast is an impossibility. In such species it is to be assumed that an osmoregulatory mechanism is functional from the earliest stages.

In the freshwater prawns belonging to the Atyidae, a family much more primitive than the Palaemonidae and therefore, as one may suppose, established in fresh water for a still longer period, the eggs vary greatly in their size, and 
there are many small-egged forms which are certainly unable to migrate into brackish water.

What little we know of the reproductive habits and life history of Palaemon is sufficient to show that relative independence of the medium during developmental stages has not been attained at least in some species of an essentially freshwater genus, and it seems that although osmotic adaptation for freshwater life was achieved by the adults of Leander, a similar independence of the environment was not attained during larval life for embryonic or osmotic reasons. The habit of liberating the larvae in salt water, in an environment involving less osmotic work, may have brought about the slow suppression of the migratory habit, at least in some species of the Palaemoninae, until they became secondarily established in brackish water and finally in the sea.

\section{SUMMARY}

I. The brackish-water prawn Palaemonetes varians and the marine prawns Leander serratus and L. squilla are hypotonic in normal sea water, the blood of these species showing osmotic pressures equivalent to $2 \cdot 3,2.8$ and $2.6 \% \mathrm{NaCl}$ respectively, in an external medium of $3.5 \% \mathrm{NaCl}$.

2. Palaemonetes varians is isotonic in water of about $2.0 \% \mathrm{NaCl}$ and the species is practically homoiosmotic, the difference in its osmotic pressure over a range of $5.0 \% \mathrm{NaCl}$ in the external medium being only $0.8-\mathrm{I} \cdot 0 \%$. The species has a very wide range of tolerance from water that is nearly fresh to concentrated sea water equivalent to $5 \cdot 2 \% \mathrm{NaCl}$.

3. Leander serratus is much less homoiosmotic than Palaemonetes, and has a limited tolerance to dilution and concentration of the environment. Homoiosmoticity is maintained up to a dilution of $2.5 \%$ in the external medium when isotonicity is reached; but in lower dilutions there is a steady decline in osmotic pressure and the regulatory mechanism evidently breaks down.

4. The osmotic behaviour of Leander squilla is very similar to that of L. serratus, but the homoiosmotic behaviour is more marked and it has greater tolerance to dilution of the environment.

5. When Leander and Palaemonetes are transferred to very dilute sea water, the internal osmotic pressure falls gradually for about I4-24 hr., varying according to the size of the individual. After the lowest value has been registered there is a slight rise, and a steady state is thereafter maintained.

6. Studies on the changes of weight of prawns when transferred to diluted media indicate that the integument (gills) is permeable to water and that, at least in Leander serratus, the amount of water entering is mainly responsible for the dilution of the blood. There is a similar fall in weight when prawns are transferred to concentrated media, due to loss of water.

7. The urine of Palaemonetes and Leander is nearly isotonic with the blood irrespective of the nature of the external medium in which the animal is placed. This suggests that the kidneys do not play a significant part in the 
osmoregulation, not even in examples of Palaemonetes acclimatized to nearly fresh water.

8. The contents of (I) the dorsal sac, (2) the nephroperitoneal sac, and (3) the urinary bladder of Leander serratus have been separately removed and the osmotic pressures determined. They do not present significant differences; hence a salt reabsorbing or a water reabsorbing mechanism is absent in the excretory organs.

9. The osmotic changes during the moult cycle of $L$. serratus have been studied. There is a slight rise in the osmotic pressure of prawns about to moult and the value comes down to normal a few days after the moult. A prawn of fresh weight of I g. absorbs about $0.3 \mathrm{~g}$. of water during moulting.

Io. The gills of palaemonid prawns are definitely permeable to water in both directions and, to a slight extent, to salts. As compared with stenohaline animals, however, the permeability of the gills of Leander and Palaemonetes is shown to be very low, and especially so in Palaemonetes.

II. Both Palaemonetes and Leander drink the external medium as judged by experiments with dyes. This behaviour is, however, erratic and occurs even when in hypotonic media. The evidence is insufficient to assume that water drinking is essential for osmoregulation.

I2. The prawns are able to assimilate ions from dilute solutions presumably through the gills. Part of the absorption of salts may also take place through the gut wall.

13. The possible occurrence of some salt-excreting mechanism is emphasized; probably in the gills. It has not been cytologically proved, but attention is drawn to the excretory cells occurring in the gills. The osmoregulatory role of the gill in the light of its histological structure is discussed.

I4. Palaemonid prawns seem to achieve osmotic stability by active absorption of ions when in hypotonic media and there is strong circumstantial evidence for active transport of water against the osmotic gradient, probably very effective when in hypertonic media. The osmotic work required for adjustment is brought to a minimum by the low permeability of the integument (gills), which gives the prawns considerable powers of salt retention.

I5. The significance of the osmotic behaviour of Palaemonetes and Leander in the evolutionary history of the Palaemoninae is discussed. It is suggested that Leander serratus and $L$. squilla are probably species that have taken secondarily to marine life.

\section{ACKNOWLEDGEMENTS}

I have great pleasure in acknowledging my indebtedness to Prof. D.M.S. Watson for his continual interest and advice in this work and the hospitality of his department where the work was begun and the necessary apparatus assembled. My thanks are due to Prof. A.V. Hill for permission to work in his laboratory to learn the thermoelectric method and to Mr J.L. Parkinson for technical advice and assistance. To Dr E. J. Allen I am deeply indebted for 
his advice and criticism throughout the course of the investigation, and also for the loan of his sections of Palaemonetes. Dr W.R.G. Atkins has also been most helpful in discussing problems of osmosis. Finally, I am very grateful to Dr S.W. Kemp for the generous facilities given me for this work at Plymouth and his criticism of the paper; his intimate knowledge of problems of distribution has been of invaluable assistance. The work was carried out during the tenure of an Overseas Scholarship of the Royal Commission for the Exhibition of I85I.

\section{ADDENDUM}

While this paper was in the press there has appeared an account of the osmotic pressure relations of nine species of crabs of the Pacific coast of N. America (Lowell L. Jones, I94I. F. Cell. Comp. Physiol., Vol. xviII, pp. 79-92). Of special interest is the fact that Uca crenulata shows remarkable powers of regulation and is even hypotonic in sea water, its behaviour being very much like that of the semi-terrestrial crabs examined by Pearse (vide Table I, p. 3I9). Pachygrapsus crassipes has been found to produce urine isotonic with blood. In Hemigrapsus, which has an osmotic pressure curve similar to that of Carcinus, a higher temperature seems to induce a slightly higher osmotic pressure. The author brings some evidence to indicate that crabs showing ability to maintain hypotonicity in sea water are better adapted for terrestrial life than others capable only of hyperosmotic regulation.

\section{REFERENCES}

Allen, E. J., I892a. On the minute structure of the gills of Palaemonetes varians. Quart. F. Micr. Sci., Vol. xxxIv, pp. 75-84.

I892 b. Nephridia and body cavity of some decapod Crustacea. Quart. F. Micr. Sci., Vol. xxxiv, pp. 403-26.

Atkins, W. R. G., I922. The hydrogen-ion concentration of sea water in its biological relations. F. Mar. Biol. Assoc., Vol. xII, pp. 717-69.

BALDES, E. J., I934. A micro-method of measuring osmotic pressure. F. Sci. Instr., Vol. XI, pp. 223-5.

BALDWIN, E., I937. Introduction to Comparative Biochemistry. Cambridge.

BATEMAN, J. B., I933. Osmotic and ionic regulation in the shore crab Carcinus maenas with notes on the blood concentrations of Gammarus locusta and Ligia oceanica. F. Exp. Biol., Vol. x, pp. 355-7I.

BAUMBerger, J. P. \& Dill, D. B., I928. A study of the glycogen and sugar content and the osmotic pressure of crabs during the moult cycle. Physiol. Zoöl., Vol. I, pp. 545-9.

BAumberger, J. P. \& Olmsted, J. M. D., I928. Changes in the osmotic pressure and water content of crabs during the moult cycle. Physiol. Zoöl., Vol. I, pp. 531-44.

BEADLE, L. C., I939. Regulation of the haemolymph in the saline water mosquito larva of Aedes detritus Edw. F. Exp. Biol., Vol. xvi, pp. 346-62.

Beadle, L. C. \& CRAGG, J. B., I940 $a$. Studies on adaptation to salinity in Gammarus spp. I. F. Exp. Biol., Vol. xvII, pp. 437-44.

I940b. Osmotic regulation in fresh-water animals. Nature, Lond., Vol. CXLVI, p. 588. 
BETHE, A., I929. Ionendurchlässigkeit der Körperoberfläche von wirbellosen Tieren des Meeres als Ursache der Giftigkeit von Seewasser abnormer Zusammensetzung. Pflüger's Arch., Vol. CCXxI, pp. 344-62.

- 1930. The permeability of the surface of marine animals. F. Gen. Physiol., Vol. XIII, pp. 437-44.

BETHE, A. \& BERGER, E., I93I. Variation im Mineralbestand verschiedener Blutarten. Pflüger's Arch., Vol. ccxxvir, pp. 571-84.

BoAs, J. E. V., I 898. Kleinere carcinologische Mittheilungen. (2) Über den ungleichen Entwicklungsgang der Salzwasser, und der Süsswasserform von Palaemonetes varians. Zool. Fahrb., Abt. Syst., fena, Vol. Iv, pp. 793-804.

Bottazzi, F., I897. La pression osmotique du sang des animaux marins. Arch. Ital. Biol., Vol. xxviII, pp. 6I-72.

_ 1908. Osmotischer Druck und elektrische Leitfähigkeit der Flüssigkeiten der einzelligen pflanzlichen und tierischen Organismen. Ergebn. Physiol., Vol. vII, pp. $16 \mathrm{I}-402$.

ClaUS, ARNOLD, 1937. Vergleichend-physiologische Untersuchungen zur Ökologie der Wasserwanzen mit besonderer Berücksichtigung der Brackwasserwanze Sigara lugubris Fieb. Zool. Fahrb., Abt. Allg. Zool., Fena, Vol. LvIII, pp. 365-432.

ConkLIN, R. E. \& KROGH, A., I938. A note on the osmotic behaviour of Eriocheir in concentrated, and Mytilus in dilute sea water. Z. Vergl. Physiol., Vol. xxvi, pp. 239-4I.

COOPER, L. H. N., I932. On the effect of long-continued additions of lime to aquarium sea water. F. Mar. Biol. Assoc., Vol. xvIII, pp. $20 \mathrm{I}-2$.

Cú́not, L., I895. Études physiologiques sur les Crustacés Décapodes. Arch. Biol., Vol. xIII, p. 245; Vol. xIv, p. 293.

DAKIN, W. J. \& EDMONDS, E., I93I. The regulation of the salt contents of the blood of aquatic animals, and the problem of the permeability of the bounding membranes of aquatic invertebrates. Australian. F. Exp. Biol. Med. Sci., Vol. virI, pp. I70-87.

Delaunay, H., I931. L'excrétion azotée des Invertébrés. Biol. Rev., Vol. vi, pp. 265-301.

DrACH, P., I936. L'eau absorbée au cours de exuviation donnée fundamentale pour l'étude physiologique de la mue. C.R. Acad. Sci., Paris, Vol. CcII, p. I8I7.

— 1939. Mue et cycle d'intermue chez les Crustacés Décapodes. Ann. Inst. Océanogr. Monaco, Vol. xIx, pp. I03-391.

Drilhon, A., 1933. La glucose et la mue des Crustacés. C.R. Acad. Sci., Paris, Vol. CLXLVI, pp. 506-IO.

Duval, M., 1925. Recherches physico-chimiques et physiologiques sur le milieu intérior des animaux aquatiques. Modifications sous l'influence du milieu extérieur. Ann. Inst. Océanogr. Monaco, Vol. II, pp. 232-407.

EDMONDS, E., I935. The relations between the internal fluid of marine invertebrates and the water of the environment, with special reference to Australian Crustacea. Proc. Linn. Soc. N.S.W., Vol. Lx, pp. 233-47.

Faxon, W., I879. On the development of Palaemonetes vulgaris. Bull. Mus. Comp. Zool. Harvard, Vol. v, pp. 303-30.

FRÉDÉRICQ, L., I904. Sur la concentration moléculaire du sang et des tissus chez les animaux aquatiques. Arch. Biol., Vol. xx, pp. 70I-39.

FrITZSCHE, H., I9I7. Studien über Schwankungen des osmotischen Druckes der Körperflüssigkeiten bei Daphnia magna. Int. Rev. Hydrobiol., Vol. vIII, pp. 22-80.

Gray, J., I931. Experimental Cytology, pp. I-5I6. Cambridge.

Grobben, C., I880. Die Antennendrüse der Crustaceen. Arb. Zool. Inst. Wien, Vol. III, pp. 93-IIo.

GuRNEY, R., I923. Some notes on Leander longirostris and other British prawns. Proc. Zool. Soc. Lond., Vol. xiII, pp. 97-125. 
GuRney, R., 1939. A description of the adult and larval stages of a new species of Palaemonetes from the Marianne Islands. Annot. Zool. Fap., Vol. xvIII, pp. I45-55.

HARNISCH, O., I934. Osmoregulation und osmoregulatorischer Mechanismus der Larve von Chironomus thummi. Z. Vergl. Physiol., Vol. xxi, pp. 28I-95.

Henderson, J. R. \& Matthai, G., igro. On certain species of Palaemon from South India. Rec. Ind. Mus., Vol. v, pp. 277-305.

Herrmann, Fr., I93I. Über den Wasserhaushalt des Fluss-Krebses (Potamobius astacus). Z. Vergl. Physiol., Vol. xIv, pp. 479-524.

HILL, A. V., I930. A thermal method of measuring the vapour pressure of an aqueous solution. Proc. Roy. Soc., A, Vol. cxxvII, pp. 9-I9.

- 1931. Adventures in Biophysics, pp. I-162. Oxford.

HuF, E., 1936. Der Einfluss des mechanischen Innendrucks auf die Flüssigkeitsausscheidung bei gepanzerten Süsswasser- und Meereskrebsen. Pflüger's Arch., Vol. cCXxxvII, pp. 240-50.

Hukuda, K., I932. Change of weight of marine animals in diluted media. F. Exp. Biol., Vol. IX, pp. 6I-8.

Kemp, S., I915. Fauna of the Chilka Lake: Decapoda. Mem. Ind. Mus., Vol. v, pp. $200-325$.

- 1925. Notes on Crustacea Decapoda of the Indian Museum XVII. Rec. Ind. Mus., Vol. xxvII, pp. 249-343.

KEYS, A. B., I93I. Chloride and water secretion and absorption by the gills of the eel. Z. Vergl. Physiol., Vol. xv, pp. 364-89.

- I933. The mechanisms of adaptation in the common eel and the general problem of osmotic regulation in fishes. Proc. Roy. Soc., B, Vol. cxir, pp. I84-99.

Keys, A. \& Willmer, E. N., 1932. 'Chloride-secreting cells' in the gills of fishes with special reference to the common eel. F. Physiol., Vol. Lxxvi, pp. 368-77.

KocH, H., I934. Essai d'interprétation de la soi-disant 'réduction vitale' de sels d'argent par certains organes d'Arthropodes. Ann. Soc. Sci. Phys. Bruxelles, B, Vol. LIV, pp. 346-6I.

- I938. The absorption of chloride ions by the anal papillae of diptera larvae. F. Exp. Biol., Vol. xv, pp. 152-60.

Kowalevsky, W., I889. Ein Beitrag zur Kenntnis der Exkretionsorgane. Biol. Zbl., Vol. IX, pp. 33-47.

KROGH, A., I937. Active absorption of ions in the animal kingdom. Nature, London, Vol. cxxxix, p. 755 .

- I938. The active absorption of ions in some fresh-water animals. Z. Vergl. Physiol., Vol. xxv, pp. 335-50.

- 1939. Osmotic Regulation in Aquatic Animals, pp. I-242. Cambridge.

KuENEN, D. J., I939. Systematic and physiological notes on the brine shrimp, Artemia. Arch. Néerland. Zool., Vol. III, pp. 365-449.

LienemanN, L. J., I938. The green glands as a mechanism for osmotic and ionic regulation in the crayfish (Cambarus clarkii Girard). F. Cell. Comp. Physiol., Vol. XI, pp. I47-6I.

Lowndes, A. G. \& PANIKKar, N. K., I94I. A note on the changes in water content of the lobster (Homarus vulgaris M. Edw.) during moult. F. Mar. Biol. Assoc., Vol. XXv, pp. III-I2.

MaLUf, N. S. R., I937. The permeability of the integument of the crayfish (Cambarus bartoni) to water and electrolytes. Biol. Zbl., Vol. LVII, pp. 282-7.

- 1938. Physiology of excretion among the Arthropoda. Physiol. Rev., Vol. xvirI, pp. $28-58$.

I939a. The blood of arthropods. Quart. Rev. Biol., Vol. xIV, pp. I49-9I.

I $1939 b$. On the anatomy of the kidney of the crayfish and on the absorption of chloride from fresh water by this animal. Zool. Fahrb., Abt. Allg. Zool., Fena. From Abstract in Biol. Abstracts, Vol. xiv, p. 234, Abst. 2380. 
MARCHAL, P., I892. Recherches anatomiques et physiologiques sur l'appareil excréteur des Crustacés décapodes. Arch. Zool. Exp. Gén., Sér. 2, Vol. x, pp. 75-275.

Margaria, R., I93I. The osmotic changes in some marine animals. Proc. Roy. Soc., B, Vol. CviI, pp. 606-24.

Mathias, P., I938. Sur la résistance de Palaemon squilla L. et de Crangon vulgaris F. à la diminution de salure de l'eau. Bull. Soc. Zool. France, Vol. LxiII, pp. 337-43.

Medwedewa, N. B., 1927. Über den osmotischen Druck der Hämolymphe von Artemia salina. Z. Vergl. Physiol., Vol. v, pp. 547-54.

Menon, M. KRISHNA, I938. The early larval stages of two species of Palaemon. Proc. Indian Acad. Sci., B, Vol. virI, pp. 288-94.

Mollitor, A., 1937. Beiträge zur Untersuchung des Exkretstoffwechsels und der Exkretion von Eriocheir sinensis H. Milne-Edwards. Zool. Fahrb., Abt. Allg. Zool., fena, Vol. LVII, pp. 323-54.

NAGEL, H., I934. Die Aufgaben der Exkretionsorgane und der Kiemen bei der Osmoregulation von Carcinus maenas. Z. Vergl. Physiol., Vol. xxI, pp. 468-9I.

NeEDHAM, J., I930. On the penetration of marine organisms into fresh-water. Biol. Zbl., Vol. L, pp. 504-9.

- 1937. Chemical Embryology, Vol. III. London.

NouvelL, L., 1933. Sur la croissance et la fréquence des mues chez les crustacés décapodes Natantia. Bull. Soc. Zool. France, Vol. LvirI, pp. 7I-5.

Olmsted, J. M. D. \& Baumberger, R. J. P., I923. Form and growth of grapsoid crabs. F. Morph., Vol. xxxviII, pp. 279-94.

Oтто, I. P., I937. Ueber den Einfluss der Temperatur auf den osmotischen Wert der Blutflüssigkeit bei der Wolkhandkrabbe (Eriocheir sinensis H. Milne-Edwards). Zool. Anz., Vol. cxix, pp. 98-105.

PanikKar, N. K., I937. The prawn industry of the Malabar coast. F. Bombay Nat. Hist. Soc., Vol. xxxix, pp. 343-53.

- I939. Osmotic behaviour of Palaemonetes varians (Leach). Nature, London, Vol. CXLIV, p. 866.

- I940a. Osmotic properties of the common prawn. Nature, London, Vol. CXLv, p. 108.

I $1940 \mathrm{~b}$. Influence of temperature on osmotic behaviour of some crustacea and its bearing on problems of animal distribution. Nature, London, Vol. CLXVI, p. 366 .

- I94I. Osmotic behaviour of the fairy shrimp, Chirocephalus diaphanus Prev. F. Exp. Biol., Vol. xviII, pp. Iro-I4.

PANikKar, N. K. \& AiYar, R. G., I937. The brackish-water fauna of Madras. Proc. Indian Acad. Sci. B, Vol. vi, pp. 284-337.

Panikkar, N. K. \& Sproston, N. G., I94I. Osmotic relations of some metazoan parasites. Parasitology, Vol. xxxII, pp. 214-23.

Pantin, C. F. A., I93I. Origin of the composition of the body fluids in animals. Biol. Rev., Vol. vI, pp. 459-82.

Patwardhan, S. S., I937. Palaemon. Indian Zoological Memoirs, Lucknow, Vol. vI, pp. I-IOO.

PeArSE, A. S., I932. Freezing-points of blood of certain littoral and estuarine animals. Pap. Tort. Lab. Carn. Inst. Washington Publ., 435, Vol. xxvIII, pp. 93-102.

Peters, H., I935. Über den Einfluss des Salzgehaltes im Aussenmedium auf den Bau und die Funktion der Exkretionsorgane von Dekapoden Crustaceen (nach Untersuchungen an Potamobius fluviatilis und Homarus vulgaris). Z. Morph. Ökol. Tiere, Vol. xxx, pp. 355-8r.

Picken, L. E. R., I936. The mechanism of urine formation in invertebrates. I. The excretion mechanism in certain Arthropoda. F. Exp. Biol., Vol. xIII, pp. 309-28. 
PorA, E. A., 1938. Behaviour of Palaemon squilla to variation in salinity. Ann. Sci. Univ. Fassy, Vol. xxiv (II), pp. 327-3r. (From Chem. and Physiol. Abstracts, I938, A, Vol. III, p. 934.)

- 1939. Sur le comportement des Crustacés brachyoures de la Mer Noire aux variations de salinité du milieu ambiant. Ann. Sci. Univ. Fassy, Vol. xxv, pp. I-34.

RoberTson, J. D., I937. Some features of the calcium metabolism of the shore crab (Carcinus maenas). Proc. Roy. Soc. B, Vol. cxxiv, pp. I62-82.

I939. Ionic composition of the blood of some marine animals. F. Exp. Biol., Vol. XVI, pp. 387-97.

SCHLIEPER, C., I929. Ueber die Einwirkung niederer Salzkonzentrationen auf marine Organismen. Z. Vergl. Physiol., Vol. Ix, pp. 478-5I4.

— I930. Die Osmoregulation wasserlebender Tiere. Biol. Rev., Vol. v, pp. 30956.

I935. Neure Ergebnisse und Probleme aus dem Gebiet der Osmoregulation wasserlebender Tiere. Biol. Rev., Vol. x, pp. 334-6o.

SCHLIEPER, C. \& HERRMANN, F., 1930. Beziehungen zwischen Bau und Funktion bei den Exkretionsorganen von Dekapoden Crustaceen. Zool. Fahrb., Abt. Anat., fena, Vol. LII, pp. 624-30.

SCHNAKENBECK, W., I933. Leander longirostris (H. M.-Edw.) in der Unter-Elbe. Zool. Anz., Vol. cII, pp. I29-35.

SCHOLles, W., 1933. Über die Mineralregulation wasserlebender Evertebraten. Z. Vergl. Physiol., Vol. xIx, pp. 522-54.

Schwabe, E., I933. Über die Osmoregulation verschiedener Krebse. Z. Vergl. Physiol., Vol. xIx, pp. I83-236.

Sexton, E. W. \& Matthews, A., I9I3. Note on the life history of Gammarus chevreuxii. F. Mar. Biol. Assoc., Vol. Ix, pp. 546-56.

SMITH, Homer W., I930. The absorption and excretion of water and salts by marine teleosts. Amer. F. Physiol., Vol. xcIII, pp. 480-505.

Sollaud, E., I923. Le dévelopement larvaire des Palaemoninae, I: La condensation progressive de l'ontogénèse. Bull. Biol. France et Belg., Vol. LVII, pp. 510-603.

— 1932. Le développement du Palaemonetes mesopotamicus Pesta, comparé à celui des autres Palaemonetes circaméditerranéens. C.R. Acad. Sci., Paris, Vol. cxcIV, pp. 2233-5.

Vialli, M., I925. La pressione osmotica negli invertebrati. Arch. Fisiologia, Vol. xxIII, pp. 577-96.

WebB, D. A., I940. Ionic regulation in Carcinus maenas. Proc. Roy. Soc. London, B, Vol. CXxIx, pp. I07-36.

Weldon, W. F. R., I889. The coelom and nephridia of Palaemon serratus. F. Mar. Biol. Assoc., Vol. I, pp. I62-8.

- I89I. The renal organs of certain decapod crustacea. Quart. F. micr. Sci., Vol. xxxiI, pp. 279-92.

Widmann, E., I935. Osmoregulation bei einheimischen Wasser- und FeuchtluftCrustaceen. Z. Wiss. Zool., Vol. CXLVII, pp. 132-69.

WIGGLESWORTH, V. B., I933. The adaptation of mosquito larvae to salt water. F. Exp. Biol., Vol. x, pp. 27-37.

1938. The regulation of osmotic pressure and chloride concentration in the haemolymph of mosquito larvae. F. Exp. Biol., Vol. xv, pp. 235-47.

YoNGE, C. M., I932. On the nature and permeability of chitin. I. The chitin lining the foregut of decapod crustacea and the function of the tegumental glands. Proc. Roy. Soc. B, Vol. CxI, pp. 298-329.

— 1936. On the nature and permeability of chitin. II. The permeability of uncalcified chitin lining the foregut of Homarus. Proc. Roy. Soc. B, Vol. cxx, pp. I5-4I. 